\title{
Adherence between steel bars and lightweight concrete with EPS beads
}

\section{Aderência entre barras de aço e concreto leve com pérolas de EPS}
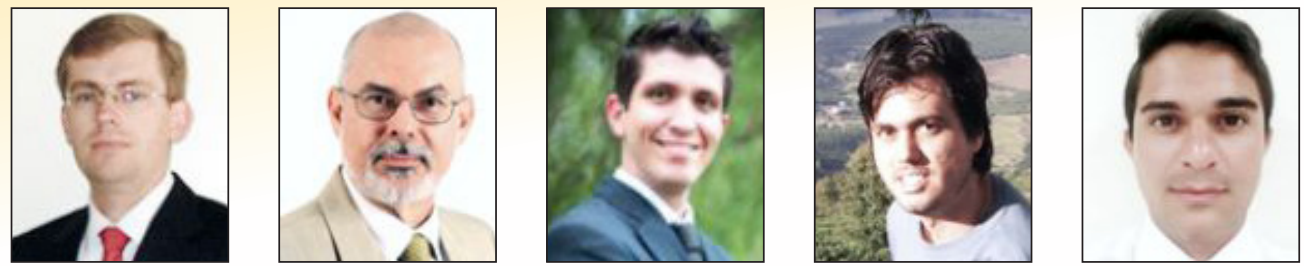

A. L. SARTORI artur.sartorti@ucb.org.br

L. M. PINHEIRO b libanio@sc.usp.br

R. M. DA SILVA ${ }^{\circ}$ raphael.vertice@live.com

S. B. FREITAS a samuelfreitas1985@gmail.com

T. G. CESAR d tiago.cesar.15@hotmail.com

\begin{abstract}
This paper describes the adherence behavior of a structural lightweight concrete with EPS beads (SLCEB) in a monotonic loading, based in a bibliographic review and in pull-out tests. The results of these SLCEB tests were compared with those of an ordinary concrete (OC) and with the values based in indications of the Brazilian code ABNT NBR 6118:2014 - Design of concrete structures. The pull-out tests of two batches of SLCEB and one of $\mathrm{OC}$ were analyzed, in a total of 60 tests. Mechanical characteristics were determined too, such as: compressive strength and tensile strength in split cylinder test. The calculated results according to the above mentioned standard were very different from those obtained in the tests, indicating that the theoretical values are more conservative than the experimental ones. It was also verified that it is possible to use SLCEB in structures with respect to the adequate adherence of reinforcement in the concrete.
\end{abstract}

Keywords: lightweight concrete with EPS, anchoring by adherence, sliding, splitting, adherence stress.

\section{Resumo}

Este artigo descreve o comportamento da aderência de um concreto leve estrutural com pérolas de EPS (CLEPE) sob carregamento monotôni$\mathrm{co}$, com base em revisão bibliográfica e em ensaios de arrancamento. Os resultados desses ensaios de CLEPE foram comparados com os de um concreto convencional (CC) e com os valores baseados nas recomendações da ABNT NBR 6118:2014 - Projeto de estruturas de concreto. Foram analisados os ensaios de arrancamento de dois lotes de CLEPE e um de CC, totalizando 60 ensaios. Também foram determinadas características mecânicas, tais como: resistência à compressão e resistência à tração por compressão diametral. Os resultados calculados de acordo com a norma citada foram muito diferentes dos obtidos nos ensaios, indicando que os valores teóricos são mais conservadores do que os experimentais. Verificou-se também que é possível usar o CLEPE em estruturas, no que diz respeito à adequada aderência da armadura ao concreto.

Palavras-chave: concreto leve com EPS, ancoragem por aderência, deslizamento, fendilhamento, tensão de aderência.

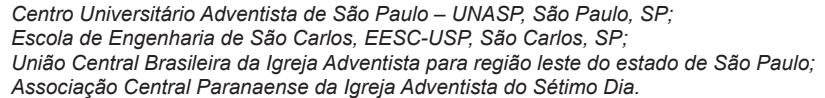




\section{Introduction}

The adherence is responsible for solidary behavior between steel and concrete. Its failure is brittle, thus, it must be avoided.

Nowadays, the application of lightweight concrete in sctructures intensifies the necessity of a study about adherence between steel bars and these new concretes, in order that the rules for anchorage calculation and splice length are established (SILVA, FREITAS and CESAR [1]).

Lightweight concrete with EPS beads (LCEB) is the focus material of this article. The expanded polystyrene (EPS) is an oil derivative and has $98 \%$ of empties, and it is used in SLCEB to reduce the specific weigth until $50 \%$ or more, when it is compared with the ordinary concrete (OC), according to Catoia [2].

SLCEB is a new material in the technical area and has some peculiar characteristics that follow the reduction of density. Decrease of compressive strength, alteration in the tensile strength, and change in the bond strength between steel and concrete can be mentioned among these characteristics.

In this work, a theoretical basis about steel-concrete adherence is described, and then, results obtained in laboratory are mentioned and they can be used for an estimate of bond strength steel-SLCEB.

\section{Structural lightweight concrete with EPS beads}

Commonly, the term "concrete" refers to something solid and has a substantial weight. The association of the term "light" to the concrete can cause some perplexity to ordinary people that wouldn't expect such a characteristic in a concrete.

However, the need to improve specific characteristics like the reduction of self weight led the science of concrete to develop special solutions, including the lightweight concrete.

The lightweight concrete can be definied as a material characterized by low density compared to ordinary concretes. Neville [3] mentions that the practical range of the density of lightweight concretes is from $300 \mathrm{~kg} / \mathrm{m}^{3}$ to $1800 \mathrm{~kg} / \mathrm{m}^{3}$. However, nothing prevents that other densities outside this range can also be considered as belonging to lightweight concretes.

ACl 213R-87 [4] classifies the lightweight concrete in three groups in function of the specific weigth, which is influenced directly by cement content and type of lightweight aggregate that is used, whose origin can be natural or artificial, according to Sbrighi Neto [5]. These groups are: insulating concretes, which are designed especially to composition of thermal insulation partition walls; concretes with moderate strength, which have application in fillers of floors, and in others with less responsibility; and structural concretes that must have a minimum strength of $17 \mathrm{MPa}$.

The use of lightweight concretes begun 1850 years ago in Roman pantheon that was rebuilt after a fire, by emperor Adriano (AIITCIN [6]. An interesting historical report can be found in Rossignolo and Agnesini [7], and Rossignolo and Agnesini [8], which emphasize the application of lightweight concretes in iconic projects and large size, like high buildings and big bridges.

The conception of lightweight concrete with expanded polystyrene (EPS) appeared with the development of the concrete technology and the constant worry about the sustainability issue.
The Expanded Polystyrene Brazilian Association - ABRAPEX [9] defines lightweight concrete with EPS as a cement and sand concrete, which in place of crushed stone, uses EPS in a way of expanded beads or recycled flakes. When the mixture of cement and sand is hardened it involves EPS particles, which volume is constituted from $95 \%$ to $98 \%$ of air, providing a concrete with low density.

The study of lightweight concrete with expanded polystyrene (EPS) is indicated by Chen et al. [10] as being started in 1973. In recent years, some researches and experimental studies conducted to a great development in the technology of lightweight concrete with EPS, as the works of Catoia [2] and Sartorti [11].

Mixture design, strengths, creep, shrinkage and applications were evaluated, and also studies about durability of lightweight concrete with EPS were carried out, as those mentioned by Momtazi et al. [12]. In the research of these authors, several mixtures with the use of EPS were elaborated. Satisfactory results about water absorption by concrete, strength to electrical conductivity, and concrete in a marine environment were obtained.

Some researches have been done with lightweight concrete with EPS in Brazil like: Sant'Helena [13], that produced concretes with partial substitution of gravel aggregate by EPS in beads, in proportions from $20 \%$ to $40 \%$, reaching results that characterize lightweight concrete without structural function; Porto [14], that tested cylindrical specimens in order to obtain compression strength and elasticity modulus of "semi lightweight" concretes with normal large aggregates, and part of the volume of aggregates substituted by EPS beads; and Catoia [2], that produced an extensive characterization of lightweight concrete with EPS beads, used in this paper.

With the definition of lightweight concrete with EPS, it is noticed that there are similarities between this material and some lightweight aggregate concretes, and other similarities between it and the aerated concretes. In fact, according to Neville [3], the term concrete shouldn't be used for this material, because it has no coarse aggregates. Thus,

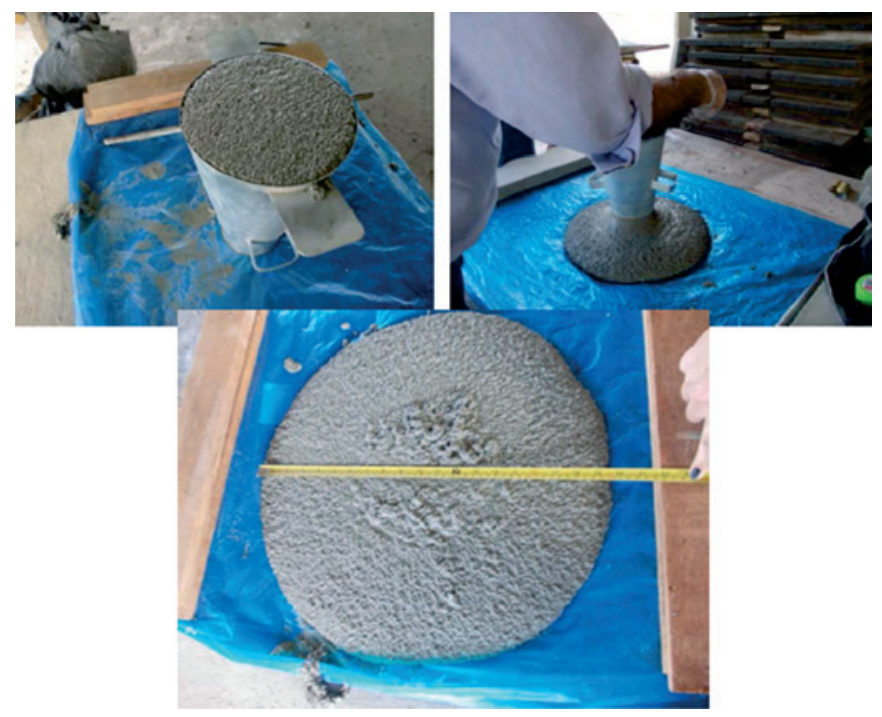

Figure 1

Slump flow test of SLCEB

From: Catoia (2), p. 55 


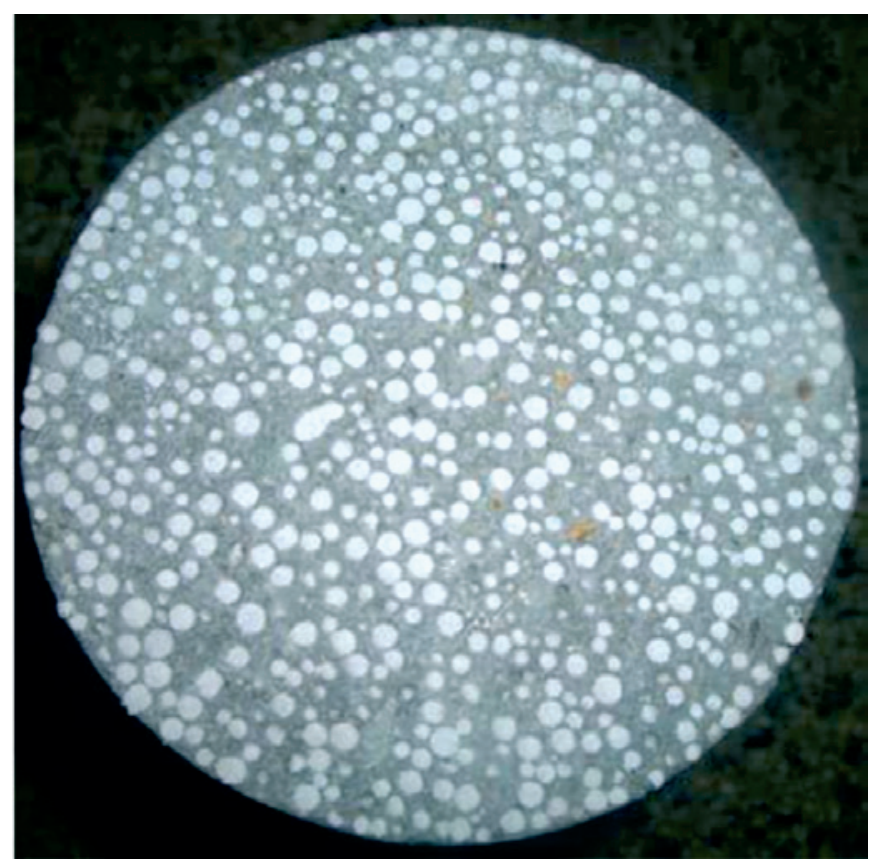

Figure 2

Appearance of solidified SLCEB

From: Catoia (2), p. 51

this paper suggests that the classification of lightweight concrete with EPS beads (variation of lightweight concrete with EPS) is framed in an intermediary way between lightweight concrete with lightweight aggregates and aerated concrete.

In general, the materials those constitute SLCEB are cement, sand, EPS (in substitution of coarse aggregate, although, it does not have the same function), water and superplasticizers. Figure 1 illustrates SLCEB in its fresh state, and figure 2 shows the rectified surface of a SLCEB cylindrical specimens.

Catoia [2] obtained results to SLCEB in three different mixtures that varied according to the amount of cement. Among several results, there are three that can be mentioned (obtained at 28 days of age). The average compressive strength varied from $13 \mathrm{MPa}$ to $17 \mathrm{MPa}$. The elasticity modulus had its variation in the range of $8 \mathrm{GPa}$ to 11 GPa. The specific weight was between $12 \mathrm{kN} / \mathrm{m}^{3}$ and $13.5 \mathrm{kN} / \mathrm{m}^{3}$. Among the most useful application of SLCEB are: partition walls, massive slabs of small and medium spans, precast in general, and ornamental pieces.

\section{Principles of steel-concrete adherence}

According to Leonhardt e Mönnig [15], the reinforced concrete has good characteristics as a material widely used in civil construction, and they are due to solidarization between the reinforcement and concrete, originating from the adherence.

The adherence can be viewed as a phenomenon that permits the operation of reinforced concrete as a structural material. Without its presence, the reinforcement would slide inside the concrete matrix, and the piece would have a similar behavior like of a structure of plain concrete.
In spite of the great importance of adherence between concrete and steel, this subject is one of the most difficult to be understood completely, according to Almeida Filho [16]. This is because of the large number of theoretical and experimental problems viewed in the study of adherence. According to Fusco [17], the adherence can be explained as a sum of three resistance mechanisms: adhesion, friction, and mechanical interlocking.

\subsection{Adherence by adhesion}

The adherence by adhesion is the resistance portion verified in the direct separation of a steel sheet from the concrete, due to a normal force to this sheet. Its origin is in the physic-chemical connections that developed in the interface of the two materials during the hydration of the cement. It has a value relatively low and practices a short influence in the total value of adherence.

\subsection{Adherence by friction}

Leonhardt and Mönnig [15] mention that when adhesion is broken by an insignificant relative displacement, the adherence by friction appears since that there are cross-pressures along the reinforcement. These cross-pressures are due to forces or the own shrinkage of the concrete.

According to Fusco [17], frictional forces also depend on the coefficient of friction between steel and concrete, which is function of surface roughness of the bar. When this roughness is very large, the resisted portion by friction is confused with the mechanical interlocking adherence.

\subsection{Mechanical interlocking adherence}

With the mechanical interlocking provided by dents (slots, cavities, recesses) and ribs of the bars, "brackets of the concrete" are formed, which are solicited for shear before the reinforcement can slide inside the concrete, according to Leonhardt e Mönnig [15]. This portion of resistance is the most effective and reliable. Fusco [17] still comments that this adherence there is also in the so-called smooth bars, due to the irregular conformation of the surface of these bars.

It's important to mention that, in practice, the separation of adherence in three portions is just schematic, because it is not possible to determine each one separately. Other factors that interfere in the behavior are indicated by Almeida Filho [16]: mixture design, temperature and humidity of the matrix; age of the concrete and values of the concrete strength to tensile; type of the bar and anchoring length; velocity of the loading and its repetition. Another very important factor is the position of reinforcement. In the upper part of concrete pieces, the exudation is larger and adhesion is damaged. The ABNT NBR 6118 [18] mentions the regions of a piece as zones of good and bad adherence. The conditions are established in the item of 9.3 .1 of this code.

\section{Failure modes of the adherence}

Almeida Filho [16] describes some types of failure mode of the adherence. It can be mentions the most important ones: elastic 
deformation, secondary cracking, cracking by longitudinal splitting, and crushing of concrete in the ribs of the longitudinal bars. Figure 3 illustrates these four modes of failure.

The sliding and pull-out of the bar are consequences of one of the modes of failure indicated in Figure 3. Usually, these failures are brittle, because they are related to the concrete. The excessive plastic deformation is an exception, which refers to the steel bar. When the lengh of anchorage is large enough to avoid fragile ruin by some modes that were mentioned (secondary cracking, longitudinal splitting, and crushing of concrete), the failure is by yielding of the steel bar. This way of failure is more ductile.

\section{Tests for determination of adherence strength}

According to Castro [19], when adherence between concrete and reinforcement is studied, it's important to notice two problems: reinforcement anchorage and concrete cracking.

The main point for anchorage by adherence is to determine the necessary length that there is transference of efforts from reinforcement to the concrete, preserving the integrity of concrete in the region of anchorage, the strength of the other bars that remain in the area that the anchored bar was interrupted, and the strength and rigidity of the bars to efforts that act in the anchored region (CASTRO [19]).

The maintenance of openings under acceptable limits is a goal for cracking of reinforcement concrete pieces. Thus, it's necessary to give an important attention to peculiarities of phenomenon that intends to study when the tests are done.
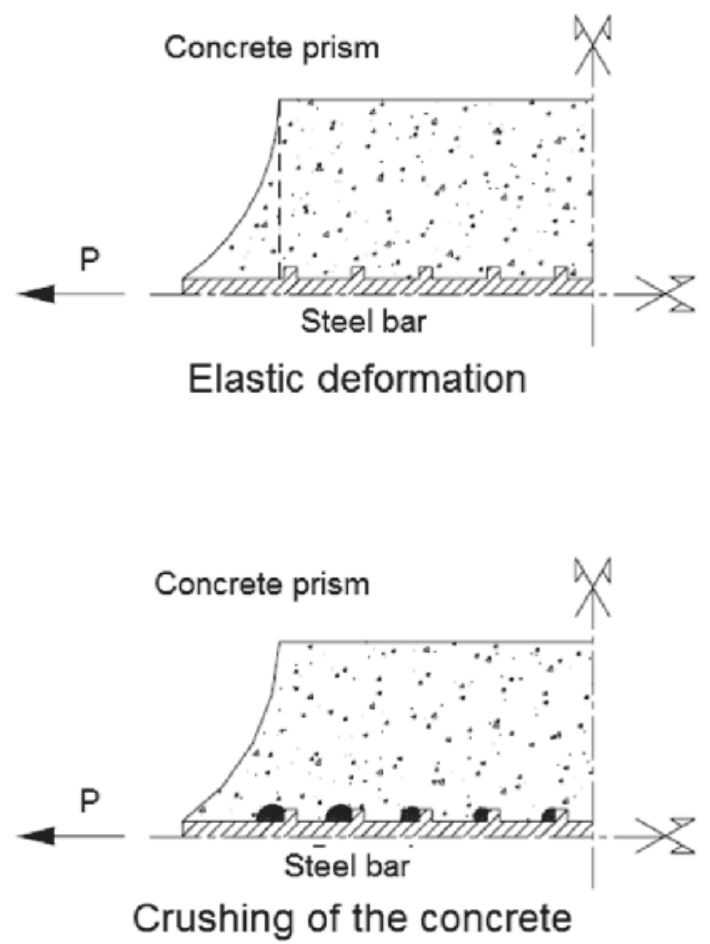

Figure 3

Failure modes of steel-concrete adherence | From: Almeida Filho (16) p. 63.

\subsection{Pull-out tests}

According to Castro [19], the adherence strength can be obtained in the pull-out tests, looking for the anchorage of the steel bars. The results of these tests are showed in a way of stress curves of adherence versus sliding, which the stress adherence and sliding are measured in the free edge of the bar.

It's difficult to measure the variation of stress along the bond length in a model with known dimensions. In the design of the anchorage regions is admitted that in failure, the adherence stress are distributed in a uniform way along the length of the anchorage. According to the practical way this hypothesis is reasonable, because it simplifies the calculation model.

This application has some backing in relation to the real behavior of the anchorage in usual applications under moderate confinement. When the forces mobilized by adherence increase, longitudinal and radial cracking are developed, which results the loss of rigidity of concrete adjacent to the bar and also in a redistribution of stress in the region of anchorage. The adherence stresses are getting more and more distributed in a uniform way before the failure, according to Castro [19].

The obtained results through pull-out tests are usually represented by average values of the adherence stress. Then, it's supposed that in the moment that the pull-out happens, there is transference of stress that acts in all length of the bar to the mass of the concrete. In this case, it can be observed that the capacity of admitted adherence to such situation results in a less value in relation to adherence stress, which can be obtained inside of these small
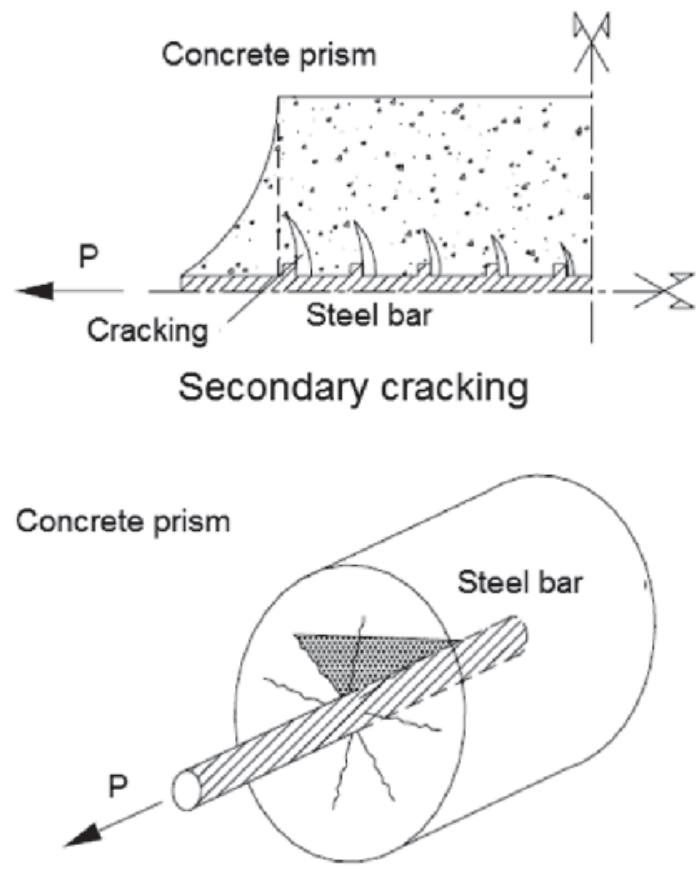

Longitudinal cracking 
intervals of anchorage. Thus, the medium values are obtained with the Equation 1:

$\tau_{b}=\mathrm{F}_{\mathrm{t}} /\left(u . l_{b}\right)$

$\tau_{b}$ is the medium adherence stress $(\mathrm{Pa}) ; \mathrm{F}_{\mathrm{t}}$ the intensity of force that requests the bar $(\mathrm{N})$; $u$ the perimeter of the bar involved by concrete $(\mathrm{m}) ; I_{b}$ the length of anchorage $(\mathrm{m})$.

Leonhardt e Mönnig [13] indicate that adherence strength of design represented by $f_{\text {bd }}$ is defined as adherence stress, for which a sliding occurs of $0,1 \mathrm{~mm}$ in the free edge of the bar. So, the strength $f_{\text {bd }}$ can be given by Equation 2 .

$\mathrm{f}_{\mathrm{bd}}=\mathrm{F}_{\mathrm{t}(\mathrm{s}=0,1 \mathrm{~mm})} /\left(u . l_{b}\right)$

$\mathrm{F}_{\mathrm{t}(\mathrm{s}=0,1 \mathrm{~mm})}$ is the intensity of the force that requires the bar, in order to occur a sliding $S$ equal to $0.1 \mathrm{~mm}$ in the edge of the bar $(\mathrm{N})$.

In this case, the effective adherence strength, in other words, the maximum adherence stress is larger than the design value $f_{\text {bd }}$, especially for bars with ribs, than can reach until the double of this value and achieve sliding with until $1 \mathrm{~mm}$. Because of safety matters, it is recommended a very distant value from the ultimate effective strength to the design, due to the large dispersal values of adherence strength (CASTRO [19]).

\subsubsection{Pull-out test according to RILEM-FIP-CEB}

One of the most known tests is the pull-out-test, proposed by RILEM-FIP-CEB [20] and illustrated by Figure 4.

According to Castro [19], the test uses a cubic specimen with a centralized bar, as indicated in the Figure 4. The steel bar is pulled out of the specimen through tensile force in the side where there is contact with support board, and the displacement of the bar is measured in relation to the concrete in the loaded edge. The average strength of the concrete in compression should be between $27 \mathrm{MPa}$ and $33 \mathrm{MPa}$, and the velocity of loading $\mathrm{V}_{\mathrm{p}}$ (in $\mathrm{kgf} / \mathrm{s}$ ) should be determined for each diameter $\varphi$ of the bar, with a value in centimeters, through Equation 3.

$\mathrm{V}_{\mathrm{p}}=5 . \varphi^{2}$

The RILEM-FIP-CEB [20] considers as reference the adherence stress to a concrete with strength to compression of $30 \mathrm{MPa}$. A tolerance in the average strength of concrete in compression $\left(f_{\mathrm{cm}}\right)$ of until $10 \%$ can be admitted. There is a linear transformation of tensile forces found in the test, through the Equation 4.

$\tau_{b}=\left(0,0637 . \mathrm{F}_{\mathrm{t} .} 30\right) /\left(\varphi^{2} \cdot \mathrm{f}_{\mathrm{cm}}\right)$

$T_{b}$ is the average adherence stress (MPa); $F_{t}$ the intensity of the force in the bar $(\mathrm{kN}) ; \varphi$ the diameter of the bar $(\mathrm{mm}) ; f_{\mathrm{cm}}$ the average strength of concrete to compression ( $\mathrm{MPa}$ ).

\subsection{Prescription of ABNT NBR 6118 about adherence}

The ABNT NBR 6118 [18] determines that in relation to the anchorage of ordinary reinforcement, the calculation of adherence strength $\left(f_{\mathrm{bd}}\right)$ between reinforcement and concrete be realized with Equation 5 . This equation provides the adherence stress for a sliding of $0.10 \mathrm{~mm}$ of the bar.

$\mathrm{f}_{\mathrm{bd}}=\left(\eta_{1} \cdot \eta_{2} \cdot \eta_{3} \cdot 0,7 \cdot 0,3 \cdot \mathrm{fck}_{\mathrm{ck}}^{2 / 3}\right) / \gamma_{\mathrm{c}}$

$f_{c k}$ is the characteristic strength of concrete to compression; $Y_{c}$ the reduction factor of the strength of the concrete, which in design is admitted in general with the value of $1.4 ; \eta_{1}$ is the parameter that considers the roughness of the steel bar (1.0 for smooth bars; 1.4 for slotted bars; 2.25 for ribbed bars); $\eta_{2}$ is the parameter that considers the position of the bar during the molding (1.0 for situation of good adherence); ( 0.7 for situation of bad adherence); $\eta_{3}$ is the parameter that considers the diameter of the bar (1.0 for diameters $\varphi \leq 32 \mathrm{~mm}$; $(132-\varphi) / 100$ for diameters $\varphi>32 \mathrm{~mm}$, with $\varphi=$ diameter of the bar in $\mathrm{mm}$ ).

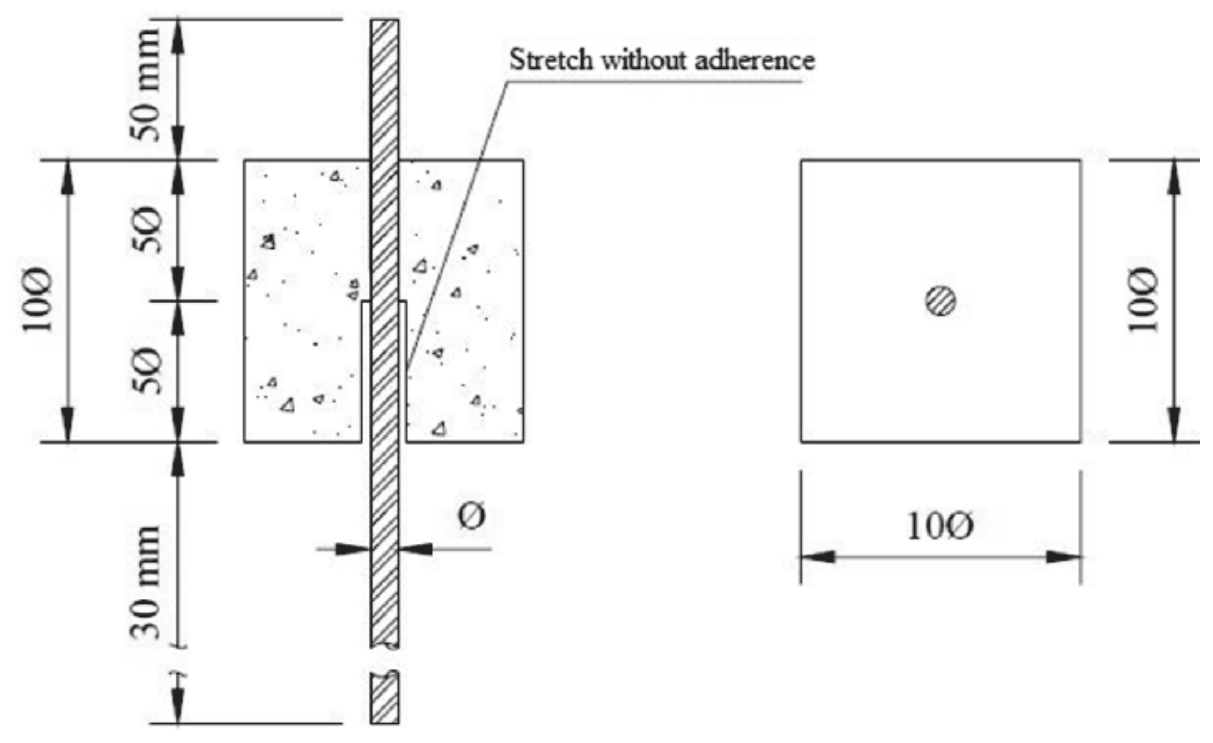

Figure 4

Specimen to the pull-out test indicated by RILEM-FIP-CEB (20) | From: CASTRO (19), p. 55 


\section{Pull-out test of embedded steel bars in SLCEB}

The pull-out tests presented in this paper totalized 60 models, including a reference mixture in Ordinary Concrete $(\mathrm{OC})$, and three mixtures o SLCEB. The Table 1 represents the characteristics of specimens tested at the Structural Engineering Department of the Sao Carlos Scholl of Engineering - University of Sao Paulo Brazil, with casting dates and of test and ages of concrete in the days of the tests.

\subsection{Material that were used}

\section{- Ordinary Concrete}

Cement of the type CP-V ARI (High Initial Strength Portland Cement) was used with an apparent and specific mass of $1095 \mathrm{~kg} /$ $\mathrm{m}^{3}$, sand with apparent and specific mass of $1628.63 \mathrm{~kg} / \mathrm{m}^{3}$, and coarse aggregates of basaltic source with apparent and specific mass equal to $2867.63 \mathrm{~kg} / \mathrm{m}^{3}$ and maximum diameter of $19 \mathrm{~mm}$.

The single sample of OC had mixture in weight of 1:2.5:2.5:0.5:0.01 (cement, sand, stone, water, and superplasticizer).

The compressive strength was measured through tests in cylindrical specimens of $100 \mathrm{~mm}$ by $200 \mathrm{~mm}$, with rectified edges. In these tests, steel supports were used and the velocity of loading was $2.4 \mathrm{kN} / \mathrm{s}$. The static characterization was realized through compression and splitting tests in cylindrical specimens of the same dimensions.

\section{- SLCEB}

The materials that were used in making of SLCEB were already described in this paper. The mixture design in weight for each batch were: preliminary test and $1^{\text {st }}$ batch $-1: 1: 0.0296: 0.32: 0.012$

Table 1

General characteristics of specimens of pull-out tests

\begin{tabular}{|c|c|c|c|c|c|}
\hline Batch & $\begin{array}{l}\text { Number of } \\
\text { Models }\end{array}$ & Diameter $(\mathrm{mm})$ & $\begin{array}{c}\text { Height of } \\
\text { concrete }(\mathrm{cm})\end{array}$ & Bond length $(\mathrm{cm})$ & Age in the test ${ }^{1}$ \\
\hline \multirow{2}{*}{ Preliminary test } & 2 & 10 & 20 & 15 & \multirow{2}{*}{24 hours } \\
\hline & 2 & 10 & 30 & 25 & \\
\hline \multirow{5}{*}{$\begin{array}{l}\text { SLCEB } \\
1^{\text {st }} \text { Batch }\end{array}$} & 4 & 5 & 9 & 4 & \multirow{5}{*}{$\begin{array}{l}29 \text { and } \\
30 \text { days }^{2}\end{array}$} \\
\hline & 4 & 6.3 & 10 & 5 & \\
\hline & 4 & 8 & 12 & 7 & \\
\hline & 4 & 10 & 14 & 9 & \\
\hline & 4 & 12.5 & 16 & 11 & \\
\hline \multirow{5}{*}{$\begin{array}{c}\text { SLCEB } \\
2^{\text {nd }} \text { Batch }\end{array}$} & 4 & 5 & 9 & 4 & \multirow{5}{*}{155 days } \\
\hline & 4 & 6.3 & 10 & 5 & \\
\hline & 4 & 8 & 12 & 7 & \\
\hline & 4 & 10 & 14 & 9 & \\
\hline & 4 & 12.5 & 16 & 11 & \\
\hline \multirow{4}{*}{$\begin{array}{l}\text { SLCEB } \\
3^{\text {nd }} \text { Batch }\end{array}$} & 4 & 5 & 5 & 2.5 & \multirow{4}{*}{127 days } \\
\hline & 4 & 6.3 & 6.3 & 3.15 & \\
\hline & 4 & 8 & 8 & 4 & \\
\hline & 4 & 10 & 10 & 5 & \\
\hline \multirow{5}{*}{ OC } & 4 & 5 & 9 & 4 & \multirow{5}{*}{$\begin{array}{l}35 \text { and } \\
36 \text { days }^{3}\end{array}$} \\
\hline & 4 & 6.3 & 10 & 5 & \\
\hline & 4 & 8 & 12 & 7 & \\
\hline & 4 & 10 & 14 & 9 & \\
\hline & 4 & 12.5 & 16 & 11 & \\
\hline
\end{tabular}




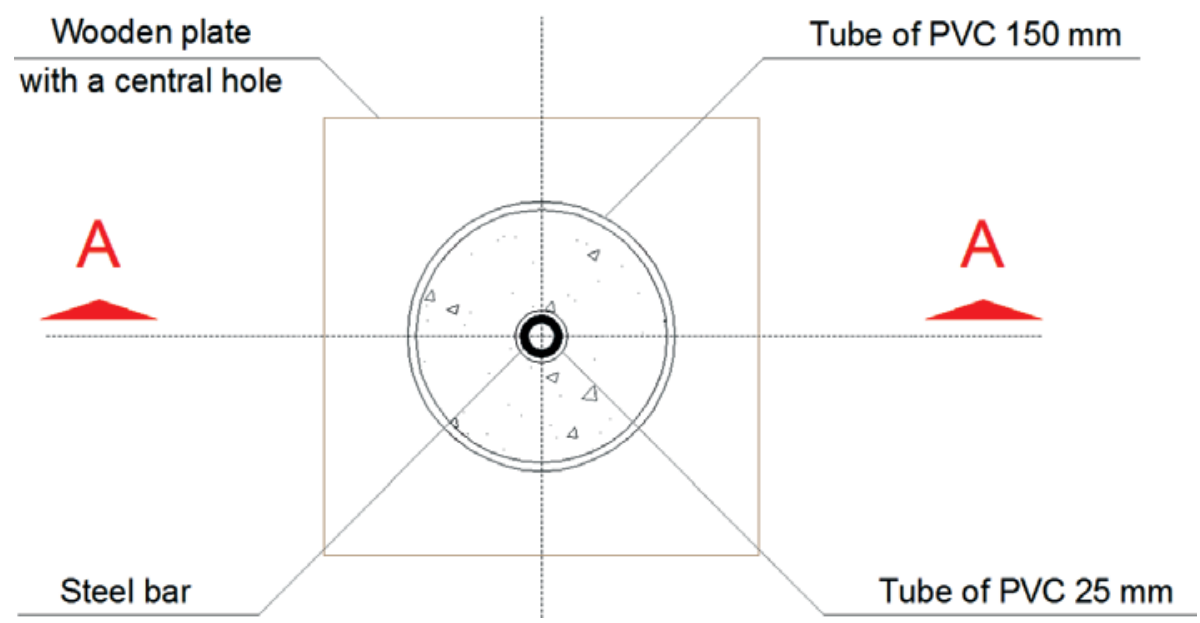

\section{Figure 5}

Project of the models

(cement, sand, EPS, water, and superplasticizer); $2^{\text {nd }}$ batch 1:1:1.35:0.34:0.013; $3^{\text {rd }}$ batch - 1:1:1.5:0.28:0.01. The strengths were measured like the OC.

Ribbed steel bars with characteristic yielding strength $f_{\mathrm{yk}}=500$ $\mathrm{MPa}$ e $f_{\mathrm{yk}}=600 \mathrm{MPa}$ were used, with nominal diameters of $5 \mathrm{~mm}$ (600 MPa); $6.3 \mathrm{~mm} ; 8 \mathrm{~mm} ; 10 \mathrm{~mm}$, and $12.5 \mathrm{~mm}$ (500 MPa). The surface of the bars of $500 \mathrm{MPa}$ is characterized by transversal ribs, inclined in relation to the axis of the bar, and for two longitudinal ribs diametrically opposed, which axes are parallel to the axis of the bar.

\subsection{Geometry of models in the pull-out tests}

The pull-out test consists in securing the concrete piece and applies a tensile force in the steel bar until it slides inside the concrete and/ or generate its splitting.

The specimens were made in cylindrical molds prepared with a tube of PVC with diameter of $150 \mathrm{~mm}$. These models were supported on a wooden board with a central hole to the passage of the steel bar. In order to minimize the effect of the transversal pressure that

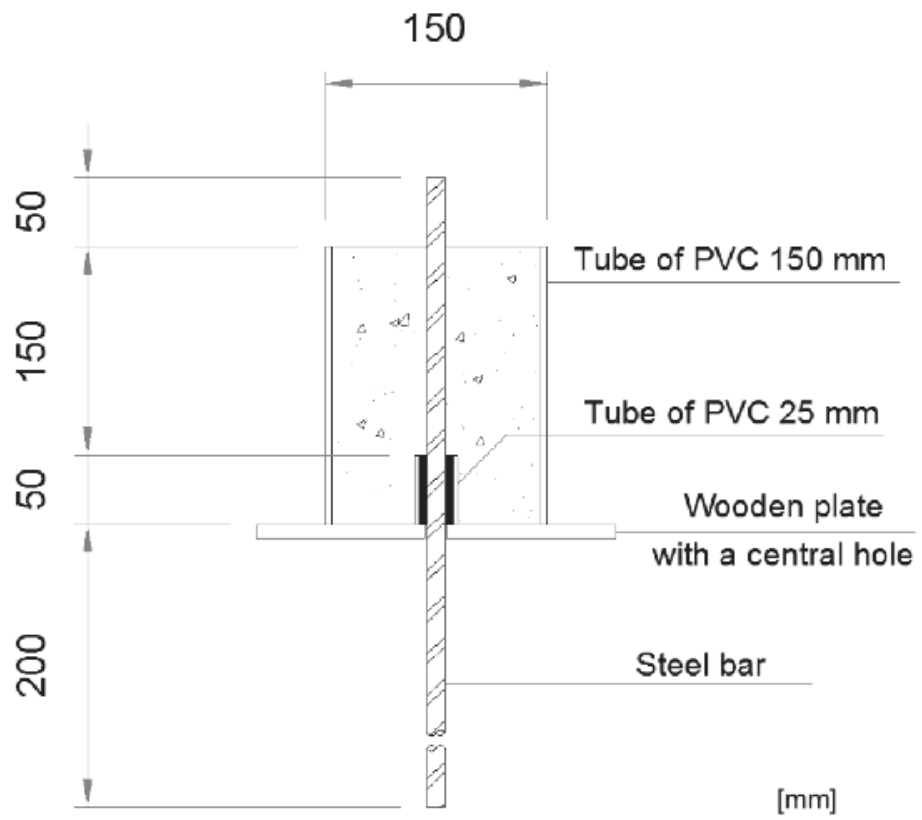

(a)
150

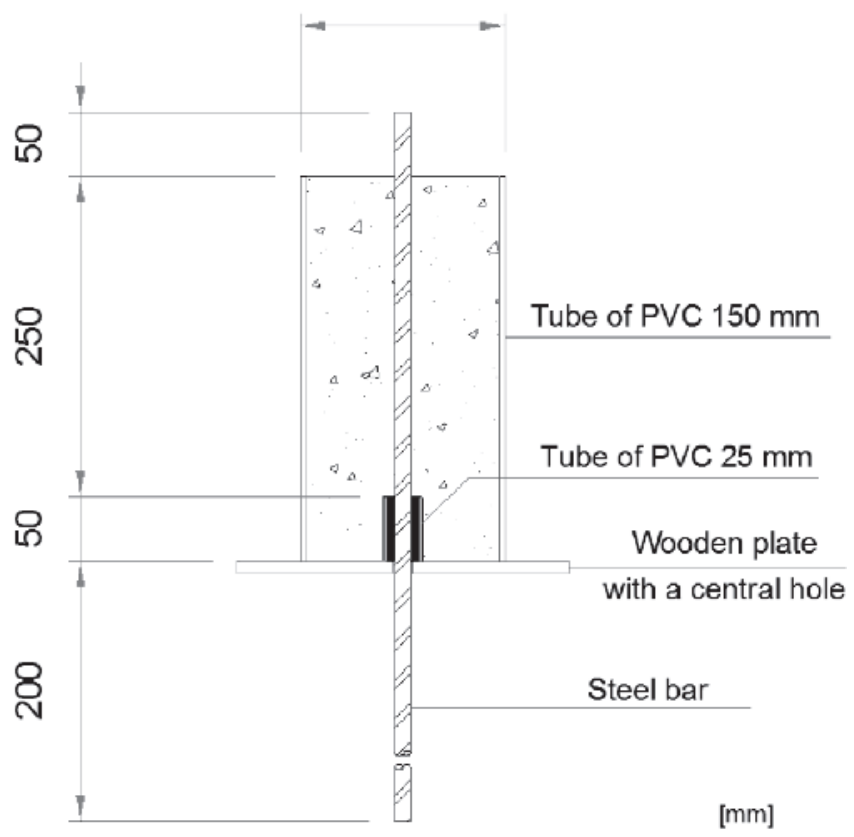

(b)

Figure 6

Molds cross section: preliminary test and $1^{\text {st }}$ batch of SLCEB (a); $1^{\text {st }}$ batch of OC (b) 
occurs due to transversal deformation impeded in the superficies of machine test, a part without adherence should be provided.

For this purpose a PVC tube with diameter of $25 \mathrm{~mm}$ and length of $50 \mathrm{~mm}$ filled with Ethyl Vinyl Acetate (EVA) was used in the casting of the specimens to prevent that concrete fill this region. The Figures 5 and 6 illustrate the molds used to cast the specimens of the preliminary test, $1^{\text {st }}$ batch of SLCEB and the only batch of OC. After execution of preliminary tests, it was verified that the length of the adherence was excessive, and it was necessary to adjust the first batches of SLCEB and OC. A part of concrete was removed with the help of a saw with a diamond disc, modifying its height and adapting to the same height of the specimens of the $2^{\text {nd }}$ batch of SLCEB.

In order to mold the other batches, the heights of molds varied according to the diameter of the steel bars $(50 \mathrm{~mm}$ more five times the diameter of the bar). The figure 7 illustrates the cross section of the model used in the casting of $2^{\text {nd }}$ and $3^{\text {rd }}$ batch of SLCEB. The figure 8 illustrates the specimen confection of pull-out tests.

\subsection{Conduction of the tests}

The specimens were separated by kind of concrete and diameter of the bars, and they were positioned in the test machine $\left(\right.$ Instron $\left.^{\circledR}\right)$ in the top part, with the steel bar in the vertical way, according the Figure 9 . In the top part of the specimens, an inductive transducer of displacement was positioned (Figure 10), and the bar was fixed by fasteners from the test equipment. After that, it was possible to start the application of the loading with velocity of $5 \mathrm{~mm} / \mathrm{s}$, and register the sliding. The velocity of displacement was adopted in view of optimization of the use time of the test machine.

\subsubsection{Preliminary tests}

Four specimens of SLCEB were separated in order to be tested with 24 hours of age, all of them with bar of $10 \mathrm{~mm}$ of diameter.

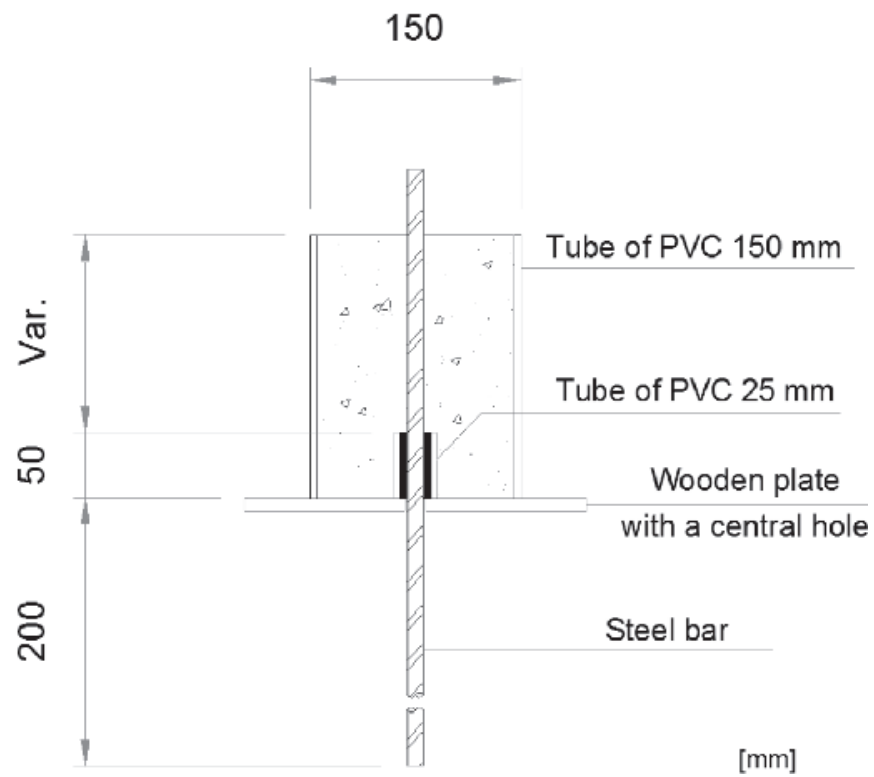

Figure 7

Molds cross section of $2^{\text {nd }}$ and $3^{\text {rd }}$ batch of SLCEB

The SP1 and SP2 with height of $300 \mathrm{~mm}$, and the SP3 with height of $200 \mathrm{~mm}$, resulted in yielding of the bar. Only the SP4 with height of $200 \mathrm{~mm}$ resulted in pull-out of the bar. Thus, it was verified that the length of adherence was very long and it would be necessary to decrease it.

\subsubsection{Definitive tests}

The definitive plan of the pull-out test was adjusted for the purpose of yielding of steel bars didn't occur. With this purpose, the recommendations of RILEM-FIB-CEB [20] were used, which

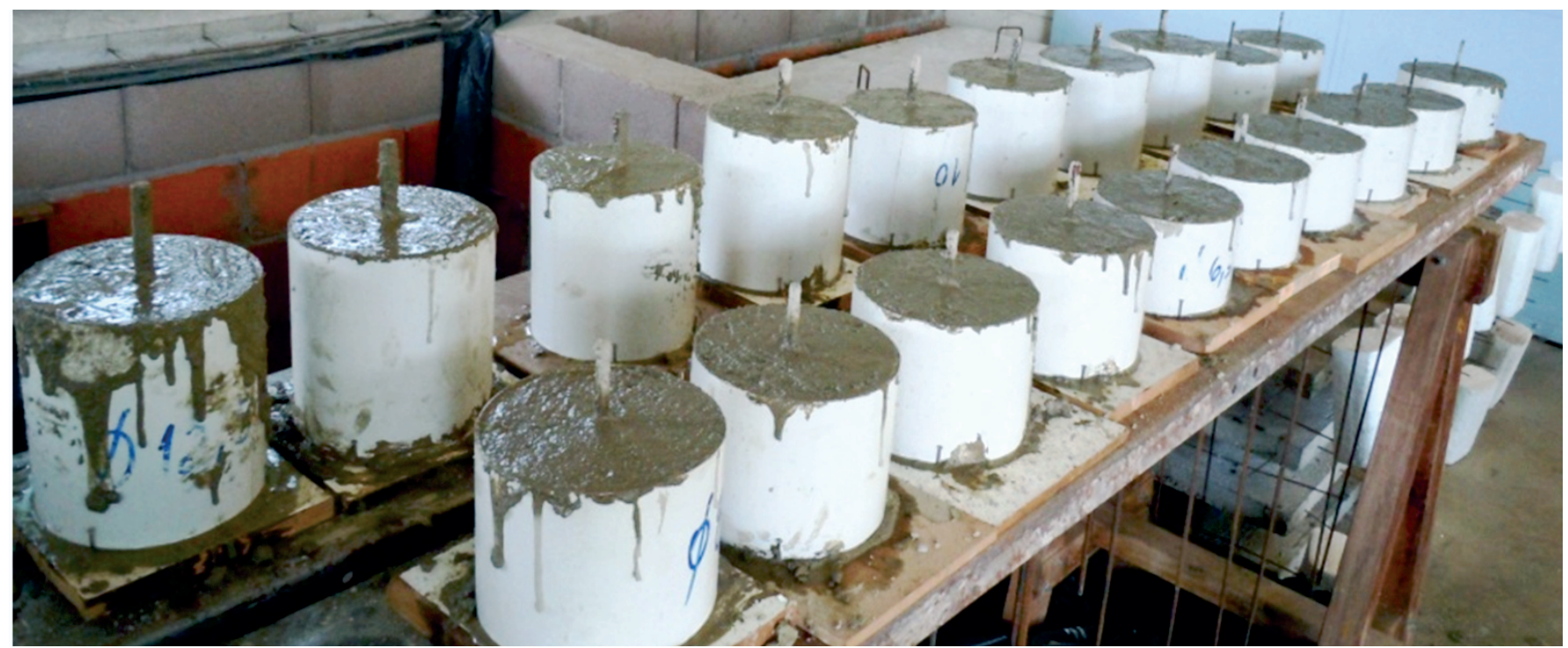

Figure 8

Casting of the specimens 


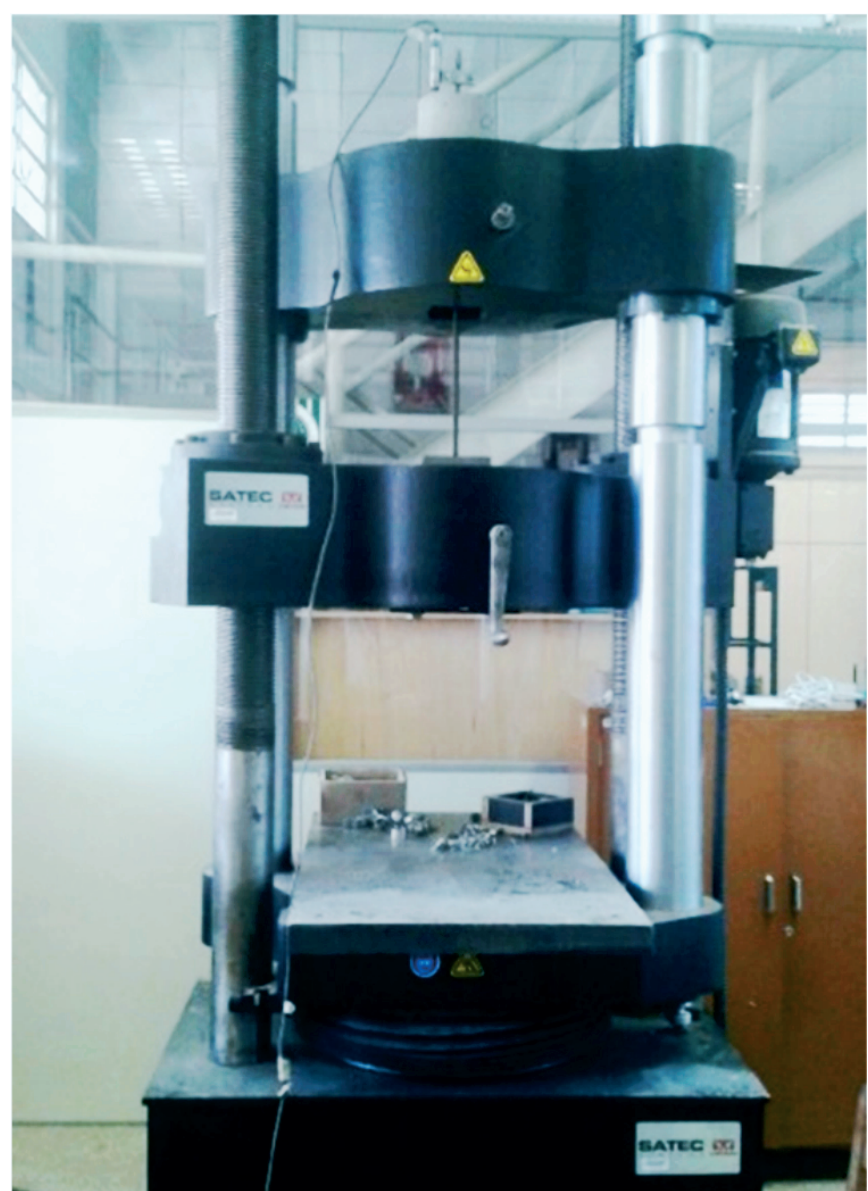

\section{Figure 9}

Position of model to a pull-out test

establish that the adherent length should be five times the diameter of the bar and the non adherent length also should be five times the diameter of the bar.

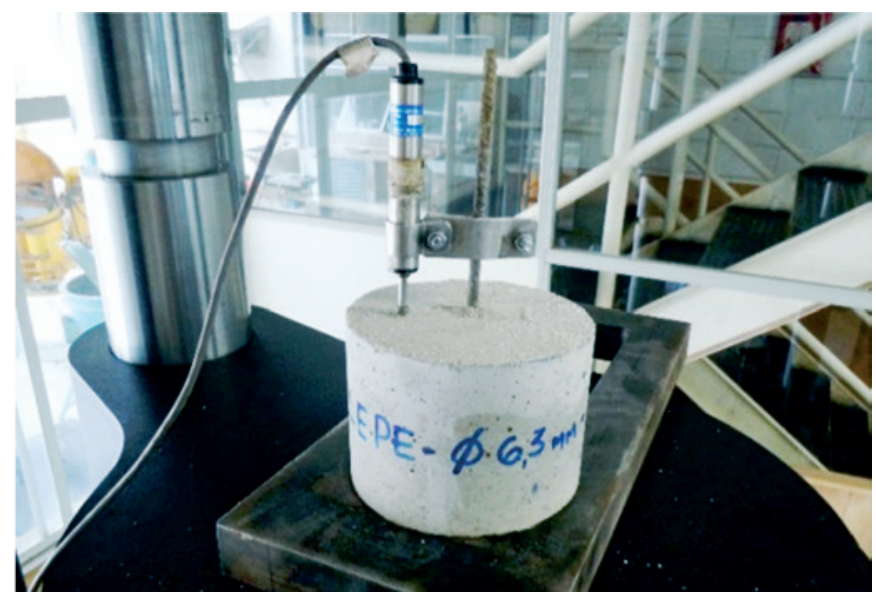

Figure 10

Position of inductive transducer of displacement

\section{Results}

The results of test are divided in two large groups. The first one refers to the tests of description of material. In the second group there are the results of pull-out tests.

\subsection{Description of concretes}

\section{- Ordinary concrete}

The description results of the batch of $\mathrm{OC}$ are presented in the table 3.

\section{- SLCEB}

The results of description of SLCEB from preliminary test of $1^{\text {st }}, 2^{\text {nd }}$, and $3^{\text {rd }}$ batch of SLCEB are described in tables 4 to 7 , respectively. As the $2^{\text {nd }}$ batch of SLCEB showed some segregation, it was discarded.

\section{Table 3}

Description of $1^{\text {st }}$ batch of $O C$

\begin{tabular}{|c|c|c|c|c|c|c|}
\hline \multirow{2}{*}{ SP } & \multicolumn{2}{|c|}{ Compression } & \multicolumn{2}{|c|}{ Splitting test } & \multirow{2}{*}{$\begin{array}{l}\text { Tension } \\
\mathrm{f}_{\mathrm{ct}}(\mathrm{MPa})\end{array}$} & \multirow{2}{*}{ Notes } \\
\hline & $F_{c i}(k N)$ & $f_{c i}(M P a)$ & $\mathbf{F}_{\mathrm{ct}, \mathrm{sp}}(\mathrm{kN})$ & $\mathrm{f}_{\mathrm{ct}, \mathrm{sp}}(\mathrm{MPa})$ & & \\
\hline 1 & 334.8 & 42.63 & 60.4 & 1.92 & 1.73 & $\begin{array}{l}\text { It didn't } \\
\text { segregate }\end{array}$ \\
\hline 2 & 348.1 & 44.33 & 86.8 & 2.76 & 2.49 & $\begin{array}{l}\text { It didn't } \\
\text { segregate }\end{array}$ \\
\hline 3 & 330.2 & 42.05 & 105.5 & 3.36 & 3.02 & $\begin{array}{l}\text { It didn't } \\
\text { segregate }\end{array}$ \\
\hline 4 & 343.4 & 43.72 & 94.0 & 2.99 & 2.69 & $\begin{array}{l}\text { It didn't } \\
\text { segregate }\end{array}$ \\
\hline Average & 339.13 & 43.18 & 86.68 & 2.76 & 2.48 & - \\
\hline
\end{tabular}


Table 4

Description of SLCEB from preliminary test

\begin{tabular}{|c|c|c|c|c|c|c|}
\hline \multirow{2}{*}{$\mathbf{S P}$} & \multicolumn{2}{|c|}{ Compression } & \multicolumn{2}{c|}{ Splitting test } & Tension & \multirow{2}{*}{ Notes } \\
\cline { 2 - 6 } & $\mathbf{F}_{\mathrm{ci}}(\mathbf{k N})$ & $\mathbf{f}_{\mathrm{ci}}(\mathbf{M P a})$ & $\mathbf{F}_{\mathrm{ctsp}}(\mathbf{k N})$ & $\mathbf{f}_{\mathrm{ct}, \mathrm{sp}}(\mathbf{M P a})$ & $\mathbf{f}_{\mathrm{ct}}(\mathbf{M P a})$ & \\
\hline 1 & 9.6 & 4.90 & 7.3 & 0.90 & 0.81 & $\begin{array}{c}\text { It didn' } \dagger \\
\text { segregate }\end{array}$ \\
\hline 2 & 13.0 & 6.60 & 8.6 & 1.10 & 0.99 & $\begin{array}{c}\text { It didn' } \dagger \\
\text { segregate }\end{array}$ \\
\hline Average & 11.3 & 5.75 & 7.9 & 1.00 & 0.90 & - \\
\hline
\end{tabular}

\section{Table 5}

Description of $1^{\text {st }}$ batch from SLCEB

\begin{tabular}{|c|c|c|c|c|c|c|}
\hline \multirow{2}{*}{$\mathbf{S P}$} & \multicolumn{2}{|c|}{ Compression } & \multicolumn{2}{c|}{ Splitting test } & Tension & \multirow{2}{*}{ Notes } \\
\cline { 2 - 6 } & $\mathbf{F}_{\mathrm{ci}}(\mathbf{k N})$ & $\mathbf{f}_{\mathrm{ci}}(\mathbf{M P a})$ & $\mathbf{F}_{\mathrm{ct}, \mathrm{sp}}(\mathbf{k N})$ & $\mathbf{f}_{\mathrm{ct}, \mathrm{sp}}(\mathbf{M P a})$ & $\mathbf{f}_{\mathrm{ct}}(\mathbf{M P a})$ & \\
\hline 1 & 93.3 & 11.88 & 41.7 & 1.33 & 1.19 & $\begin{array}{c}\text { It didn' } \dagger \\
\text { segregate }\end{array}$ \\
\hline 2 & 79.6 & 10.13 & 34.8 & 1.11 & 0.99 & $\begin{array}{c}\text { It didn' } \dagger \\
\text { segregate }\end{array}$ \\
\hline 3 & 86.3 & 10.99 & 34.0 & 1.08 & 0.98 & $\begin{array}{c}\text { It didn' } \dagger \\
\text { segregate }\end{array}$ \\
\hline 4 & 81.5 & 10.37 & 37.4 & 1.19 & 1.07 & $\begin{array}{c}\text { It didn' } \dagger \\
\text { segregate }\end{array}$ \\
\hline Average & 85.2 & 10.84 & 36.9 & 1.18 & 1.06 & - \\
\hline
\end{tabular}

\section{Table 6}

Description of $2^{\text {nd }}$ batch from SLCEB

\begin{tabular}{|c|c|c|c|c|c|c|}
\hline \multirow{2}{*}{ SP } & \multicolumn{2}{|c|}{ Compression } & \multicolumn{2}{|c|}{ Splitting test } & \multirow{2}{*}{$\begin{array}{c}\text { Tension } \\
f_{c t}(M P a)\end{array}$} & \multirow{2}{*}{ Notes } \\
\hline & $\mathrm{F}_{\mathrm{ci}}(\mathrm{kN})$ & $\mathrm{f}_{\mathrm{ci}}(\mathrm{MPa})$ & $\mathrm{F}_{\mathrm{ct}, \mathrm{sp}}(\mathrm{kN})$ & $f_{c t, s p}(M P a)$ & & \\
\hline 1 & 18.3 & 2.33 & 42.2 & 1.33 & 1.20 & It segregated \\
\hline 2 & 18.6 & 2.36 & 21.0 & 0.67 & 0.60 & $\begin{array}{c}\text { It didn'† } \\
\text { segregate }\end{array}$ \\
\hline 3 & 20.5 & 2.61 & 19.8 & 0.63 & 0.57 & $\begin{array}{l}\text { It didn't } \\
\text { segregate }\end{array}$ \\
\hline 4 & 15.0 & 1.90 & 27.0 & 0.86 & 0.77 & $\begin{array}{c}\text { It didn't } \\
\text { segregate }\end{array}$ \\
\hline Average & 18.1 & 2.30 & 27.5 & 0.87 & 0.79 & - \\
\hline
\end{tabular}

Table 7

Description of $3^{\text {rd }}$ batch from SLCEB

\begin{tabular}{|c|c|c|c|c|c|c|}
\hline \multirow{2}{*}{ SP } & \multicolumn{2}{|c|}{ Compression } & \multicolumn{2}{|c|}{ Splitting test } & \multirow{2}{*}{$\begin{array}{c}\text { Tension } \\
f_{c t}(M P a) \\
\end{array}$} & \multirow{2}{*}{ Notes } \\
\hline & $F_{c i}(k N)$ & $f_{c i}(M P a)$ & $F_{c t, s p}(k N)$ & $\mathrm{f}_{\mathrm{ct}, \mathrm{sp}}(\mathrm{MPa})$ & & \\
\hline 1 & 86.6 & 11.28 & 36.0 & 1.15 & 1.03 & $\begin{array}{c}\text { It didn'† } \\
\text { segregate }\end{array}$ \\
\hline 2 & 103.5 & 13.18 & 38.6 & 1.23 & 1.11 & $\begin{array}{l}\text { It didn'† } \\
\text { segregate }\end{array}$ \\
\hline 3 & 93.8 & 11.94 & 38.6 & 1.23 & 1.11 & $\begin{array}{l}\text { It didn'† } \\
\text { segregate }\end{array}$ \\
\hline 4 & 99.6 & 12.68 & 35.2 & 1.12 & 1.01 & $\begin{array}{l}\text { It didn'† } \\
\text { segregate }\end{array}$ \\
\hline Average & 95.9 & 12.27 & 37.1 & 1.18 & 1.06 & - \\
\hline
\end{tabular}




\section{Table 8}

Results of pull-out test in the preliminary tests of SLCEB

\begin{tabular}{|c|c|c|c|c|c|c|c|c|}
\hline $\mathbf{S P}$ & $\begin{array}{c}\mathbf{A}_{\max } \\
(\mathbf{N} . \mathbf{m})\end{array}$ & $\begin{array}{c}\mathbf{A}_{5 \mathrm{~mm}} \\
(\mathbf{N} . \mathbf{m})\end{array}$ & $\begin{array}{c}\mathbf{l}_{\mathrm{b}} \\
(\mathbf{c m})\end{array}$ & $\begin{array}{c}\mathbf{F}_{\max } \\
(\mathbf{k N})\end{array}$ & $\begin{array}{c}\mathbf{F}_{0.10 \mathrm{~mm}} \\
(\mathbf{k N})\end{array}$ & $\begin{array}{c}\tau_{\max } \\
(\mathbf{M P a})\end{array}$ & $\begin{array}{c}\tau_{0.10 m m} \\
(\mathbf{M P a})\end{array}$ & $\begin{array}{c}\mathbf{f}_{\text {bd }} \\
(\mathbf{M P a})\end{array}$ \\
\hline $1(20 \mathrm{~cm})$ & 1.21 & 39.43 & 15 & 23.3 & 21.6 & 4.95 & 4.58 & 1.01 \\
\hline $2(20 \mathrm{~cm})$ & 1.50 & 19.04 & 15 & 27.9 & 27.7 & 5.94 & 5.88 & 1.01 \\
\hline $1(30 \mathrm{~cm})$ & 1.92 & 44.95 & 25 & 42.9 & 42.5 & 5.46 & 5.41 & 1.01 \\
\hline $2(30 \mathrm{~cm})$ & 6.25 & 53.64 & 25 & 50.1 & 50.1 & 6.38 & 6.38 & 1.01 \\
\hline
\end{tabular}

Valid subtitle for Tables 8 to 11 :

$A_{\text {max }}=$ area below the curve of force versus sliding until the maxim force $F_{\text {max }}$, which the bar was submitted;

$A_{5 \mathrm{~mm}}=$ area below the curve of force versus sliding until the sliding of $5 \mathrm{~mm}$;

$\mathrm{F}_{0.10 \mathrm{~mm}}=$ force which $0.10 \mathrm{~mm}$ of bar sliding happens;

$\ell_{b}=$ bonding length of the bar;

$\tau_{\max }=$ maximum bonding stress calculated through $\mathrm{F}_{\max } /\left(\right.$ perimeter of the bar $\left.\mathrm{x} \boldsymbol{}_{\mathrm{b}}\right)$;

$\tau_{0.10 \mathrm{~mm}}=$ bonding stress to the sliding of $0.10 \mathrm{~mm}$ calculated by $F_{0.10 \mathrm{~mm}} /\left(\right.$ perimeter of the bar $\left.\times \ell_{b}\right)$;

$\mathrm{f}_{\mathrm{bd}}=$ design bonding strength in according to the item 9.3.2.1 of ABNT NBR 6118 (18).

Notes: The specimens 1 and 2 of $20 \mathrm{~cm}$ and the 1 of $30 \mathrm{~cm}$ had a failure by sliding of the bar. The SP 2 of $30 \mathrm{~cm}$ had a failure by yielding of steel.

\subsection{Pull-out tests}

The results of pull-out tests are showed in this item.

\subsubsection{Preliminary tests}

The results obtained in the preliminary test are shouwed in the table 8. The experimental curves of adherence force versus sliding of preliminary tests are showed in the figure 11. The average stress of adherence was obtained through Equation 2.

\subsubsection{Batch of OC}

The results obtained in the batch of $O C$ are showed in the table 9. The experimental curves of adherence force versus sliding are showed in the figure 12 .

\subsubsection{SLCEB - $1^{\text {st }}$ Batch}

The results obtained in the $1^{\text {st }}$ batch of SLCEB are showed in the table 10. The experimental curves of adherence force versus sliding are showed in the figure 13 . The large variety in the results

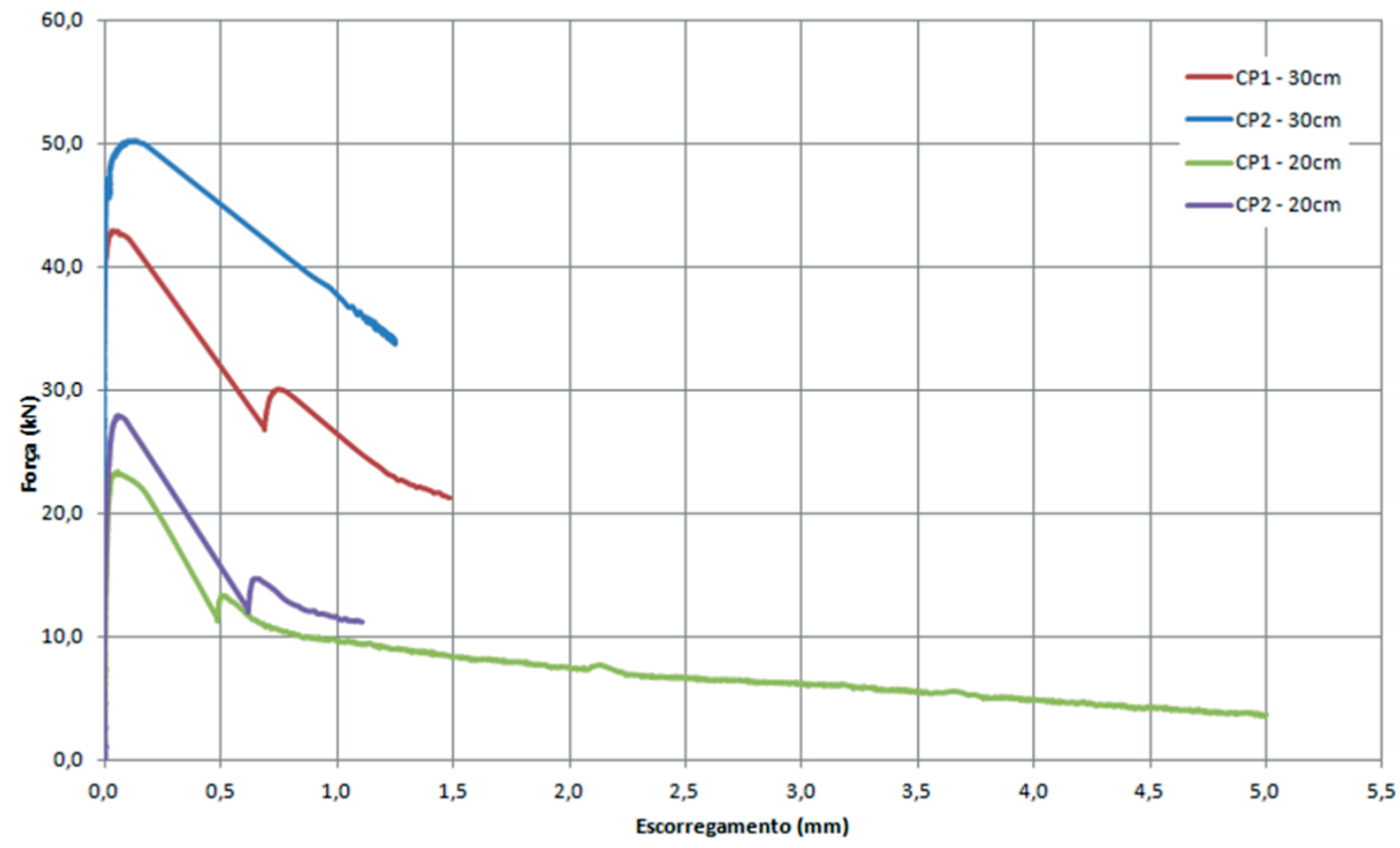

Força means Force, Escorregamento Sliding and CP stands for SP

Figure 11

Curves of force versus sliding of preliminary test 
is because of the inadequate quality of SLCEB in these tests.

\subsubsection{SLCEB $-3^{\text {rd }}$ Batch}

The results obtained to the $3^{\text {rd }}$ batch of SLCEB are showed in the table 11. The experimental curves of adherence force versus sliding are showed in the figure 14.

\section{Analysis of results}

Some analysis of test results are described in this item.

\subsection{Tests of compression}

The tests of compression showed according to it were expected that $\mathrm{OC}$ is more resistant than SLCEB. The $2^{\text {nd }}$ batch of OC showed higher strength than the $1^{\text {st }}$ batch of $O C$, which is due to the difference of mixture design.

The specimens of SLCEB showed some strength considerably lower. The $1^{\text {st }}$ and the $3^{\text {rd }}$ batch obtained similar strengths. The batch of SLCEB of the preliminary test showed a lower strength because it was tested with 24 hours of age. The $2^{\text {nd }}$ batch had segregation and showed a lower value to the other batches, and it was discarded in the rest of the research. The $3^{\text {rd }}$ batch was the best one to demonstrate the characteristics of SLCEB, because it didn't segregate and presented average strength of $12.27 \mathrm{MPa}$, higher than the others, as can be seen in the tables 4 to 7 .

\subsection{Splitting tests}

The values of strength to splitting test were proportional to the ones of compression strength. The most resistant batches to the compression are also more resistant to the splitting test, which demonstrates a relation between these two variables.

\subsection{Pull-out tests}

The average bonding strengths are showed in table 12. Through these results, it's noticed that the values of $T_{0.10 \mathrm{~mm}}$ obtained experimentally are considerably higher to the values of $f_{b d}$ based in ABNT NBR 6118 [18]. This difference was larger to SLCEB than $\mathrm{OC}$.

An interesting observation is the difference between $\mathrm{T}_{\text {máx }}$ e $\mathrm{T}_{0.10 \mathrm{~mm}}$, which to OC is about $50 \%$, and to SLCEB of $0.6 \%$ to $6.5 \%$. It

\section{Table 9}

Results of pull-out tests with models of OC

\begin{tabular}{|c|c|c|c|c|c|c|c|c|c|}
\hline $\begin{array}{c}\text { Diameter } \\
\text { of the bar } \\
(\mathrm{mm})\end{array}$ & SP & $\begin{array}{l}A_{\max } \\
\text { (N.m) }\end{array}$ & $\begin{array}{l}A_{5 \mathrm{~mm}} \\
(\mathrm{~N} . \mathrm{m})\end{array}$ & $\begin{array}{c}l_{b} \\
(\mathrm{~cm})\end{array}$ & $\begin{array}{l}\mathrm{F}_{\max } \\
(\mathrm{KN})\end{array}$ & $\begin{array}{l}F_{0.10 \mathrm{~mm}} \\
(\mathrm{kNN})\end{array}$ & $\begin{array}{c}\tau_{\max } \\
(\mathrm{MPa})\end{array}$ & $\begin{array}{l}\tau_{0.10 \mathrm{~mm}} \\
(\mathrm{MPa})\end{array}$ & $\begin{array}{c}f_{b d} \\
\text { (MPa) }\end{array}$ \\
\hline \multirow{5}{*}{5} & 1 & 6.26 & 17.82 & 4 & 6.23 & 1.47 & 9.91 & 2.34 & 2.79 \\
\hline & 2 & 9.38 & 29.28 & 4 & 9.11 & 3.85 & 14.50 & 6.13 & 2.79 \\
\hline & 3 & 12.73 & 39.03 & 4 & 10.99 & 6.18 & 17.49 & 9.84 & 2.79 \\
\hline & 4 & 12.03 & 39.03 & 4 & 10.99 & 6.18 & 17.49 & 9.84 & 2.79 \\
\hline & Average & 10.10 & 31.29 & - & 9.33 & 4.42 & 14.85 & 7.03 & 2.79 \\
\hline \multirow{5}{*}{6.3} & 1 & 17.92 & 18.21 & 5 & 22.43 & 15.11 & 22.67 & 15.27 & 2.79 \\
\hline & 2 & 22.20 & 22.64 & 5 & 21.93 & 13.64 & 22.16 & 13.78 & 2.79 \\
\hline & 3 & 30.30 & 70.97 & 5 & 19.87 & 13.55 & 20.08 & 13.69 & 2.79 \\
\hline & 4 & 24.83 & 71.03 & 5 & 20.47 & 7.05 & 20.68 & 7.12 & 2.79 \\
\hline & Average & 23.81 & 45.71 & - & 21.17 & 12.34 & 21.40 & 12.47 & 2.79 \\
\hline \multirow{5}{*}{8} & 1 & 16.97 & 67.07 & 7 & 20.47 & 10.48 & 11.63 & 5.96 & 2.79 \\
\hline & 2 & 19.90 & 90.08 & 7 & 24.72 & 14.38 & 14.05 & 8.17 & 2.79 \\
\hline & 3 & 16.70 & 92.24 & 7 & 25.78 & 17.08 & 14.65 & 9.71 & 2.79 \\
\hline & 4 & 30.04 & 92.56 & 7 & 24.68 & 13.74 & 14.03 & 7.81 & 2.79 \\
\hline & Average & 20.90 & 85.49 & - & 23.91 & 13.92 & 13.59 & 7.91 & 2.79 \\
\hline \multirow{5}{*}{10} & 1 & 34.15 & 126.88 & 9 & 37.72 & 17.08 & 13.34 & 6.04 & 2.79 \\
\hline & 2 & 40.84 & 189.90 & 9 & 47.93 & 26.97 & 16.95 & 9.54 & 2.79 \\
\hline & 3 & 25.40 & 176.02 & 9 & 47.06 & 29.30 & 16.65 & 10.36 & 2.79 \\
\hline & 4 & 27.42 & 135.16 & 9 & 35.21 & 11.72 & 12.45 & 4.15 & 2.79 \\
\hline & Average & 31.95 & 156.99 & - & 41.98 & 21.27 & 14.85 & 7.52 & 2.79 \\
\hline \multirow{5}{*}{12.5} & 1 & 88.84 & 104.66 & 11 & 62.17 & 31.36 & 14.39 & 7.26 & 2.79 \\
\hline & 2 & 41.36 & 41.36 & 11 & 61.30 & 38.73 & 14.19 & 8.97 & 2.79 \\
\hline & 3 & 48.35 & 108.81 & 11 & 66.38 & 39.05 & 15.37 & 9.04 & 2.79 \\
\hline & 4 & 83.88 & 199.10 & 11 & 65.51 & 31.22 & 15.17 & 7.23 & 2.79 \\
\hline & & 65.61 & 113.49 & - & 63.84 & 35.09 & 14.78 & 8.12 & 2.79 \\
\hline
\end{tabular}




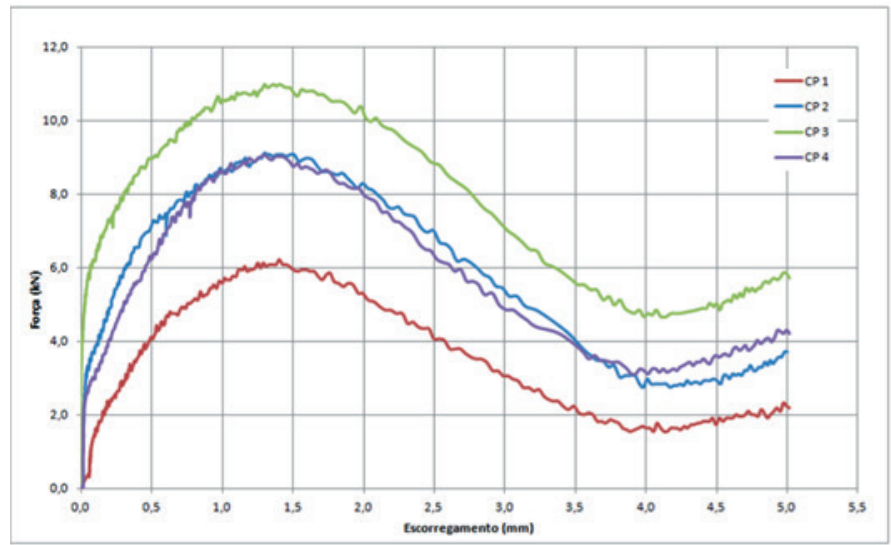

Bars of $5 \mathrm{~mm}$ of diameter

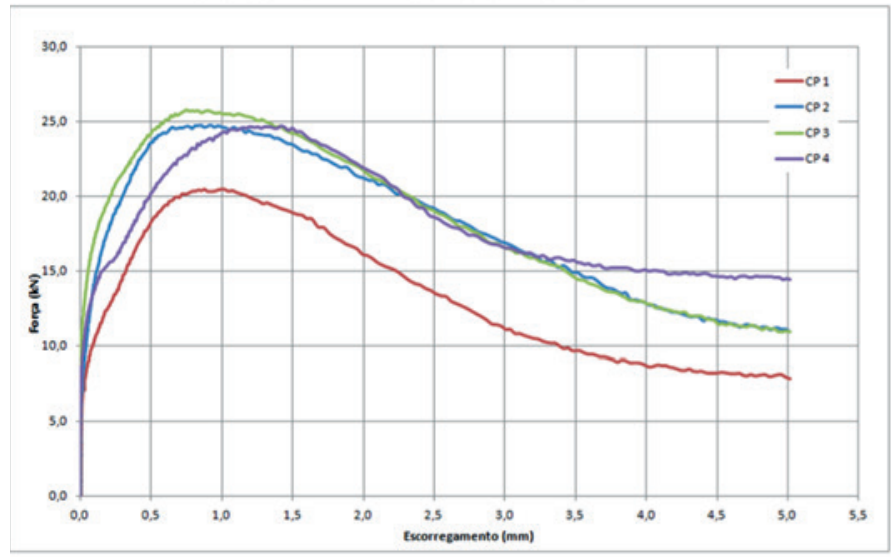

Bars of $8 \mathrm{~mm}$ of diameter

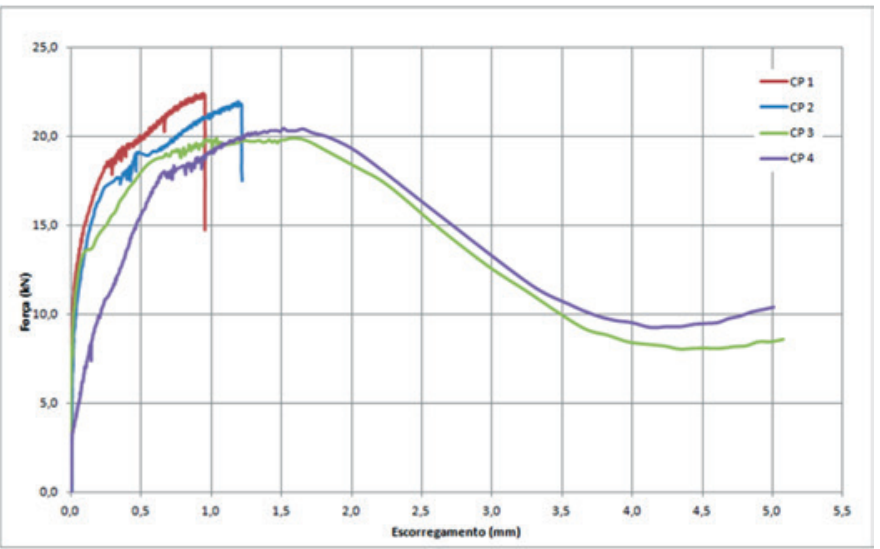

Bars of $6.3 \mathrm{~mm}$ of diameter

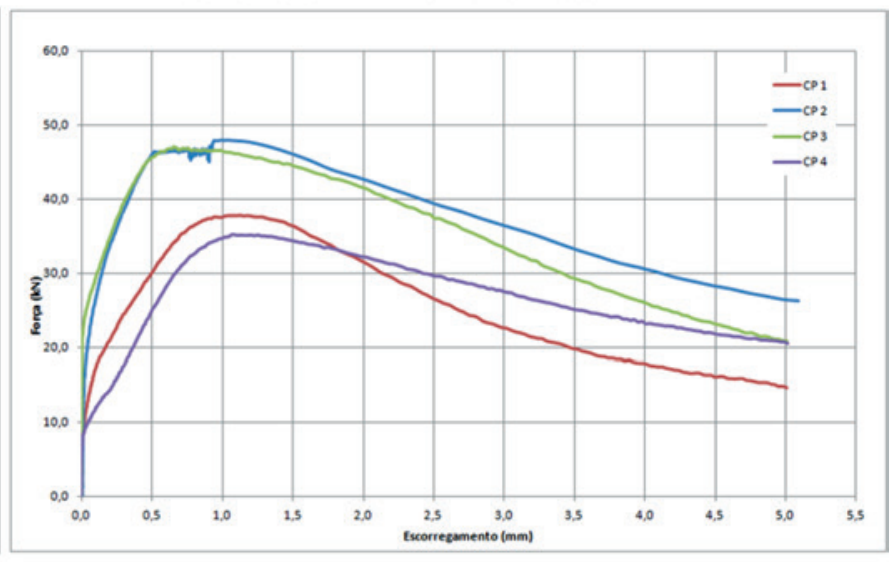

Bars of $10 \mathrm{~mm}$ of diameter

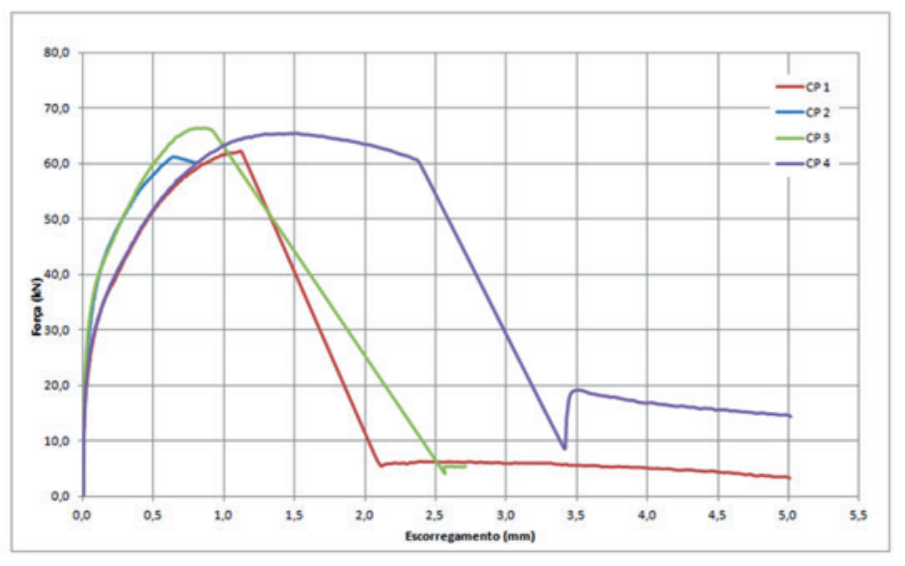

Bars of $12.5 \mathrm{~mm}$ of diameter

Figure 12

Curves of force versus sliding from batch of OC 
indicates that $\mathrm{OC}$ has a reservation of bonding strength after the splitting of $0.10 \mathrm{~mm}$, much higher than SLCEB. This reservation of strength is confirmed by tenacity (area under the curve force versus displacement), which is much higher in OC than in SLCEB. The test values showed here to $\mathrm{OC}$ are aproximated to those from Castro[19], which found a difference between $\mathrm{T}_{0.10 \mathrm{~mm}}$ and $\mathrm{f}_{\mathrm{bd}}$ of $156 \%$ to high strength concretes (medium strength of concrete to compression equal to $86 \mathrm{MPa}$ ).

Bars with larger ribs and consequently with larger diameters have the failure characterized by sliding of the steel and splitting of the concrete, as it can be observed for the bars with $12.5 \mathrm{~mm}$ of diameter.

It can be noticed by the difference between $\mathrm{T}_{0.10 \mathrm{~mm}}$ and $\mathrm{f}_{\mathrm{bd}}$ and the relative to $T_{\text {max }}$ and $T_{0.10 \mathrm{~mm}}$ that ABNT NBR 6118 [18] is very conservative to OC. However, this does not happen for SLCEB, because $\mathrm{T}_{0.10 \mathrm{~mm}}$ is very close to $\mathrm{T}_{\text {máx }}$. The technical literature justifies the conservative position of standards because of the large dispersion in the tests that have been done until now.

Another comparison can be realized between the average strength of compression (values in the Tables 3 to 7 ) and the average stress of adherence $\mathrm{T}_{\text {máx }}$ and $\mathrm{T}_{0.10 \mathrm{~mm}}$ (Table 12), showed in the Table 13. Can be observed that the magnitude of the bond stresses of SLCEB is closer to its strength to compression, while OC has a very different relation.

\section{Conclusion}

In general, the development of researches about new material is very important to the improvement of civil construction. The correct use of structural lightweight concrete with EPS beads (SLCEB), for example, possibilitates the execution of lighter structures, alleviating the loadings of foundation structures, which generates

Table 10

Results of the pull-out tests with models of $1^{\text {st }}$ Batch of SLCEB

\begin{tabular}{|c|c|c|c|c|c|c|c|c|c|}
\hline $\begin{array}{l}\text { Diameter } \\
\text { of the bar } \\
(\mathrm{mm})\end{array}$ & SP & $\begin{array}{l}A_{\max } \\
\text { (N.m) }\end{array}$ & $\begin{array}{c}A_{5 m m} \\
(N . m)\end{array}$ & $\begin{array}{c}l_{b} \\
(\mathrm{~cm})\end{array}$ & $\begin{array}{l}\mathrm{F}_{\max } \\
(\mathrm{KN})\end{array}$ & $\begin{array}{l}\mathrm{F}_{0.10 \mathrm{~mm}} \\
(\mathrm{kNN})\end{array}$ & $\begin{array}{c}\tau_{\max } \\
(\mathrm{MPPa})\end{array}$ & $\begin{array}{l}\tau_{0.10 \mathrm{~mm}} \\
(\mathrm{MPa})\end{array}$ & $\begin{array}{c}f_{b d} \\
(M P a)\end{array}$ \\
\hline \multirow{5}{*}{5} & 1 & 0.51 & 12.93 & 4 & 4.08 & 3.75 & 6.49 & 5.97 & 1.19 \\
\hline & 2 & 5.19 & 19.17 & 4 & 5.59 & 4.67 & 8,89 & 7.43 & 119 \\
\hline & 3 & 0.76 & 15.61 & 4 & 6.41 & 6.27 & 10.20 & 9.98 & 1.19 \\
\hline & 4 & 6.74 & 21.94 & 4 & 6.73 & 2.79 & 10.71 & 4.44 & 1.19 \\
\hline & Average & 3.30 & 17.41 & - & 5.70 & 4.37 & 9.07 & 6.96 & 1.19 \\
\hline \multirow{5}{*}{6.3} & 1 & 1.03 & 33.27 & 5 & 12.96 & 12.95 & 13.09 & 13.09 & 1.19 \\
\hline & 2 & 0.88 & 13.94 & 5 & 9.29 & 8.88 & 9.39 & 8.97 & 1.19 \\
\hline & 3 & 1.50 & 41.60 & 5 & 13.64 & 13.37 & 13.79 & 13.51 & 1.19 \\
\hline & 4 & 2.28 & 24.41 & 5 & 12.22 & 11.49 & 12.35 & 11.61 & 1.19 \\
\hline & Average & 1.42 & 28.30 & - & 12.03 & 11.67 & 12.16 & 11.80 & 1.19 \\
\hline \multirow{5}{*}{8} & 1 & 3.23 & 41.59 & 7 & 23.40 & 22.80 & 13.30 & 12.96 & 1.19 \\
\hline & 2 & 1.19 & 37.56 & 7 & 19.96 & 19.87 & 11.35 & 11.29 & 1.19 \\
\hline & 3 & 3.91 & 35.42 & 7 & 19.37 & 19.37 & 11.01 & 11.01 & 1.19 \\
\hline & 4 & 7.68 & 41.43 & 7 & 20.65 & 20.60 & 11.74 & 11.71 & 1.19 \\
\hline & Average & 4.00 & 39.00 & - & 20.84 & 20.66 & 11.85 & 11.74 & 1.19 \\
\hline \multirow{5}{*}{10} & 1 & 24.73 & 75.50 & 9 & 36.12 & 34.98 & 12.78 & 12.37 & 1.19 \\
\hline & 2 & 3.38 & 65.02 & 9 & 30.08 & 29.48 & 10.64 & 10.43 & 1.19 \\
\hline & 3 & 4.57 & 76.06 & 9 & 38.55 & 38.37 & 13.63 & 13.57 & 1.19 \\
\hline & 4 & 18.38 & 62.92 & 9 & 30.40 & 28.75 & 10.75 & 10.17 & 1.19 \\
\hline & Average & 12.77 & 69.88 & - & 33.79 & 32.90 & 11.95 & 11.63 & 1.19 \\
\hline \multirow{5}{*}{12.5} & 1 & 9.15 & 124.74 & 11 & 46.38 & 44.36 & 10.74 & 10.27 & 1.19 \\
\hline & 2 & 10.67 & 117.13 & 11 & 47.38 & 42.67 & 10.97 & 9.88 & 1.19 \\
\hline & 3 & 3.85 & 108.39 & 11 & 37.27 & 36.81 & 8.63 & 8.52 & 1.19 \\
\hline & 4 & 7.21 & 140.57 & 11 & 42.07 & 39.46 & 9.74 & 9.13 & 1.19 \\
\hline & Average & 7.72 & 122.71 & - & 43.28 & 40.83 & 10.02 & 9.45 & 1.19 \\
\hline
\end{tabular}




\section{Table 11}

Results of pull-out tests with models of $3^{\text {rd }}$ Batch of SLCEB

\begin{tabular}{|c|c|c|c|c|c|c|c|c|c|}
\hline $\begin{array}{l}\text { Diameter } \\
\text { of the bar } \\
(\mathrm{mm})\end{array}$ & SP & $\begin{array}{l}A_{\max } \\
(\text { N.m) }\end{array}$ & $\begin{array}{c}A_{5 \mathrm{~mm}} \\
(\mathrm{~N} \cdot \mathrm{m})\end{array}$ & $\begin{array}{c}l_{b} \\
(\mathrm{~cm})\end{array}$ & $\begin{array}{l}F_{\text {max }} \\
(\mathrm{kN})\end{array}$ & $\begin{array}{l}F_{0.10 \mathrm{~mm}} \\
(\mathrm{kNN})\end{array}$ & $\begin{array}{c}\tau_{\max } \\
(\mathrm{MPa})\end{array}$ & $\begin{array}{l}\tau_{0.10 \mathrm{~mm}} \\
(\mathrm{MPPa})\end{array}$ & $\begin{array}{c}f_{b d} \\
\text { (MPa) }\end{array}$ \\
\hline \multirow{5}{*}{5} & 1 & 2.30 & 7.75 & 2.5 & 5.31 & 5.31 & 13.52 & 13.52 & 1.19 \\
\hline & 2 & 1.43 & 8.08 & 2.5 & 5.81 & 5.54 & 14.81 & 14.11 & 1.19 \\
\hline & 3 & 2.01 & 12.01 & 2.5 & 6.68 & 6.50 & 17.02 & 16.65 & 1.19 \\
\hline & 4 & 0.42 & 11.45 & 2.5 & 4.26 & 4.26 & 10.84 & 10.85 & 1.19 \\
\hline & Average & 1.54 & 9.82 & - & 5.52 & 5.40 & 14.05 & 13.76 & 1.19 \\
\hline \multirow{5}{*}{6.3} & 1 & 0.70 & 5.84 & 3.15 & 8.06 & 8.06 & 12.92 & 12.93 & 1.19 \\
\hline & 2 & 0.53 & 8.53 & 3.15 & 7.78 & 7.65 & 12.48 & 12.27 & 1.19 \\
\hline & 3 & 3.08 & 13.47 & 3.15 & 8.74 & 8.74 & 14.03 & 14.02 & 1.19 \\
\hline & 4 & 0.48 & 13.87 & 3.15 & 7.69 & 7.65 & 12.34 & 12.27 & 1.19 \\
\hline & Average & 1.20 & 10.43 & - & 8.07 & 8.03 & 12.94 & 12.87 & 1.19 \\
\hline \multirow{5}{*}{8} & 1 & 2.04 & 27.54 & 4 & 15.89 & 15,89 & 15.80 & 15.81 & 1.19 \\
\hline & 2 & 1.32 & 22.15 & 4 & 13.09 & 13,09 & 13.02 & 13.02 & 1.19 \\
\hline & 3 & 0.88 & 30.77 & 4 & 14.24 & 14,15 & 14.16 & 14.08 & 1.19 \\
\hline & 4 & 4.61 & 20.94 & 4 & 12.59 & 12,59 & 12.52 & 12.52 & 1.19 \\
\hline & Average & 2.21 & 25.35 & - & 13.95 & 13,93 & 13.88 & 13.86 & 1.19 \\
\hline \multirow{5}{*}{10} & 1 & 4.73 & 22.16 & 5 & 17.17 & 17,16 & 10.93 & 10.92 & 1.19 \\
\hline & 2 & 12.24 & 36.39 & 5 & 21.52 & 21,52 & 13.70 & 13.70 & 1.19 \\
\hline & 3 & 10.47 & 32.94 & 5 & 20.69 & 20.69 & 13.17 & 13.17 & 1.19 \\
\hline & 4 & 11.50 & 34.37 & 5 & 18.86 & 18.86 & 12.01 & 12.01 & 1.19 \\
\hline & Average & 9.74 & 31.47 & - & 19.56 & 19.56 & 12.45 & 12.45 & 1.19 \\
\hline
\end{tabular}

savings without compromising safety and comfort.

It's important to emphasize that in a bibliographic research about SLCEB, the quantity of works about these concrete is small because this is a new material and is not yet widely used. Thus, it's necessary to have more researches about this subject.

The results obtained in experimental tests demonstrate that ABNT NBR 6118 [18] specifies conservative values to the bond strength to the ordinary concrete $(\mathrm{OC})$. It was still noticed that the maximum bond stress of SLCEB is almost equal to its strength to compression, while the OC shows $\tau_{\text {máx }}$ much higher than $\tau_{0.10 \mathrm{~mm}}$, because of its tenacity is higher. The results indicate that the order of magnitude of strength to compression of SLCEB is close to its bond stress $\tau_{0.10 \mathrm{~mm}}$

Can be concluded that SLCEB shows a bond capacity smaller than OC, which was expected due to its smaller strength. However, the smaller bond capacity does not invalidate its use, just demonstrates that this characteristic of the material should be used carefully by engineer in the design of a structure with SLCEB.

It was also verified the importance of correct preparation for concrete, because the $2^{\text {nd }}$ batch of SLCEB presented segregation due to the excess of vibration.

In order to reach the values obtained in this research, pull-out tests under monotonic action were performed. But, still there is the necessity to analyze models that represent the adherence between steel and SLCEB in dynamic tests.

The bond tests between the steel bars and SLCEB have as a goal to contribute with the necessary calculations in situations of anchorage of steel bars in structures with SLCEB.

Although, it's important to mention that the tests were done in this research should be not viewed as enough to formulate theories and assumptions of calculation. Complementary researches should be elaborated.

\section{References}

[1] SILVA, R. M.; FREITAS, S. B.; CESAR, T. G. (2014). Estudo da aderência entre barras de aço e concreto leve com pérolas de poliestireno expandido (EPS). 105f. Trabalho de Conclusão de Curso (Dissertação) - Centro Universitário Adventista de São Paulo, Engenheiro Coelho, 2014.

[2] CATOIA, T. (2012). Concreto Ultraleve ${ }^{\circledR}$ estrutural com pérolas de EPS: caracterização do material e estudo de sua aplicação em lajes. 154f. Tese (Doutorado) - Escola e Engenharia de São Carlos, Universidade de São Paulo, São Carlos, 2012.

[3] NEVILLE, A. M. (1996). Properties of concrete. 4.ed. John Wiley \& Sons, 1996. 


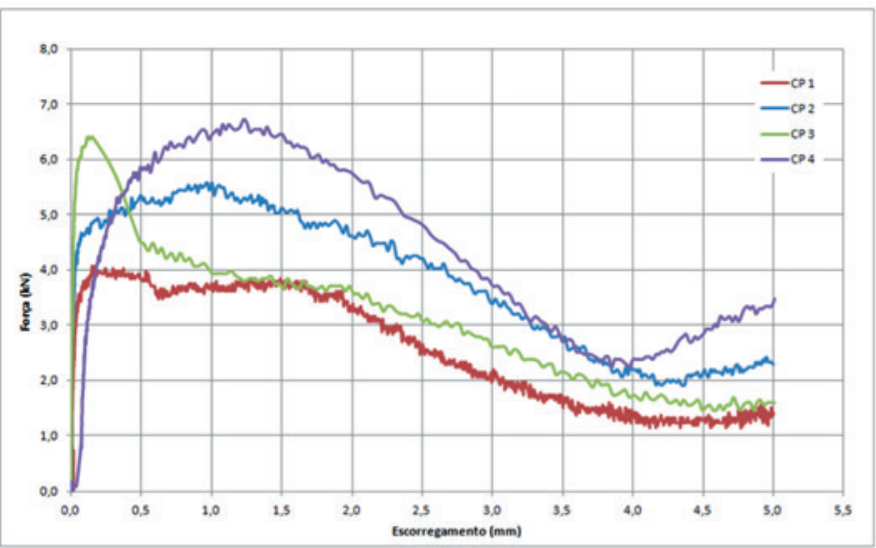

Bars of $5 \mathrm{~mm}$ of diameter

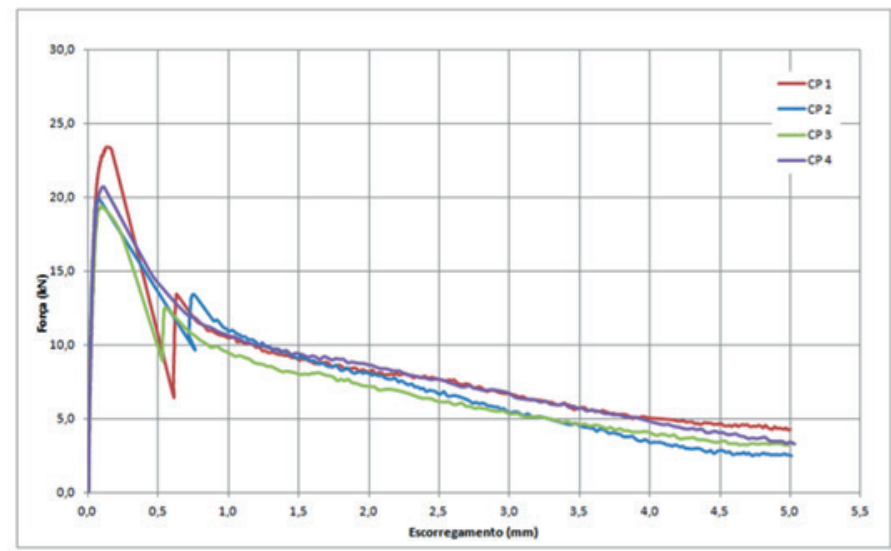

Bars of $8 \mathrm{~mm}$ of diameter

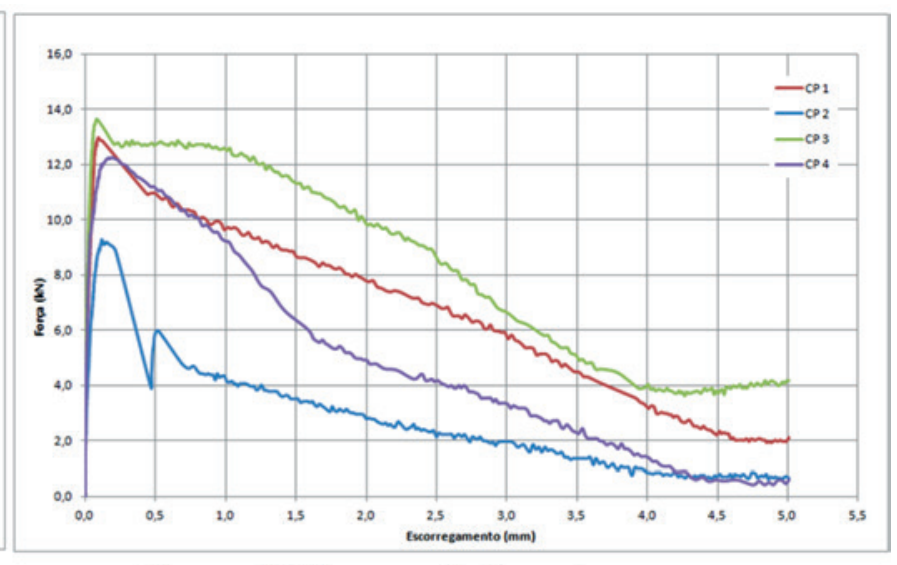

Bars of $6.3 \mathrm{~mm}$ of diameter

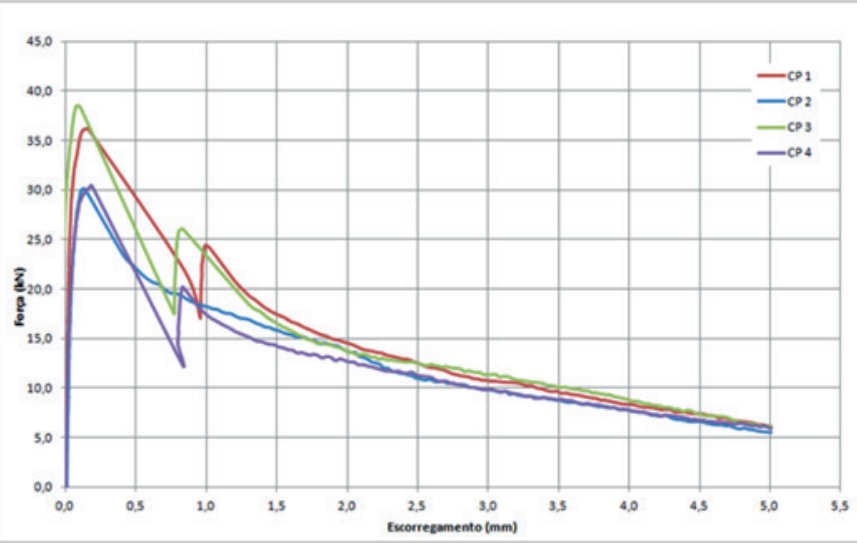

Bars of $10 \mathrm{~mm}$ of diameter

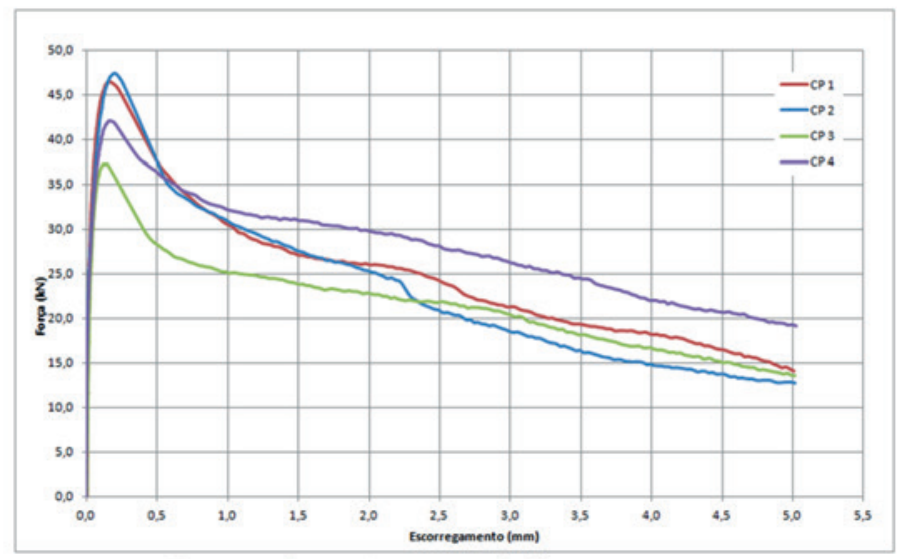

Bars of $12.5 \mathrm{~mm}$ of diameter

Figure 13

Curves of force versus sliding of the 1st batch of SLCEB 
[4] AMERICAN CONCRETE INSTITURE (ACI). ACI 213R-87: Guide for structural lightweight aggregate concrete, 1995.

[5] SBRIGHI NETO, C. (2011). Agregados naturais, britados e artificiais para concreto. In: ISAIA, G. C. Concreto: ciência e tecnologia. v.1. 1.ed. São Paulo: Ibracon. Cap.7, p.231-260.

[6] AÏTCIN, P. C. (1998). High-performance concrete. Spons Architecture Price Book.

[7] ROSSIGNOLO, J. A.; AGNESINI, M. V. C. (2005). Concreto estrutural leve. In: ISAIA, G. C. Concreto: ensino, pesquisa e realizações. v.2. 1.ed. São Paulo: Ibracon. Cap.43, p.13311362.

[8] ROSSIGNOLO, J. A.; AGNESINI, M. V. C. (2011). Concreto leve estrutural. In: ISAIA, G. C. Concreto: ciência e tecnologia. v.2. 1.ed. São Paulo: Ibracon. Cap.42, p.15311568.

[9] ASSOCIAÇÃO BRASILEIRA DO POLIESTIRENO EXPANDIDO (ABRAPEX). (2006). Manual de utilização do EPS na construção civil. São Paulo: Pini.

[10] CHEN, B.; LIU, J.; CHEN, L. (2010). Experimental study of lightweight expanded polystyrene aggregate concrete containing silica fume and polypropylene fibers. J. Shanghai
Jiaotong Univ. (Sci), Shanghai, v.15, n.2, p.129-137.

[11] SARTORTI, A. L. Comportamento Dinâmico de Lajes Maciças de Concreto Leve com Pérolas de EPS. 2015. 251p. Tese (Doutorado) - Departamento de Engenharia de Estruturas da Escola de Engenharia de São Carlos da Universidade de São Paulo, São Carlos, 2015.

[12] MOMTAZI, A. S. et al. (2010). Durability of lightweight concrete containing EPS in salty exposure conditions. In: International Conference on Sustainable Construction Materials and Technologies, 2., 2010, Ancona. Proceedings... Ancona: Università Politecnica delle Marche. p.1-10.

[13] SANT'HELENA, M. (2009). Estudo para aplicação de poliestireno expandido (EPS) em concretos e argamassas. 87f. Monografia (Trabalho de Conclusão de Curso) Departamento de Engenharia Civil, Universidade do Extremo Sul Catarinense, Criciúma, Santa Catarina, 2009.

[14] PORTO, V. K. J. (2010). Análise experimental de concreto leve estrutural em função dos agregados graúdos. 92f. Monografia (Trabalho de Conclusão de Curso) - Curso de Engenharia Civil, Centro Universitário Adventista de São Paulo, Engenheiro Coelho, 2010.

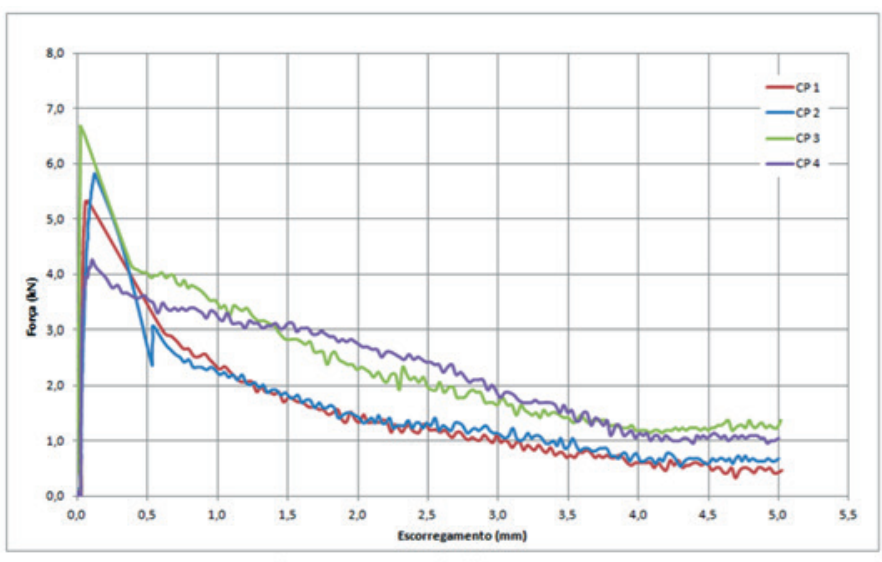

Bars of $5 \mathrm{~mm}$ of diameter

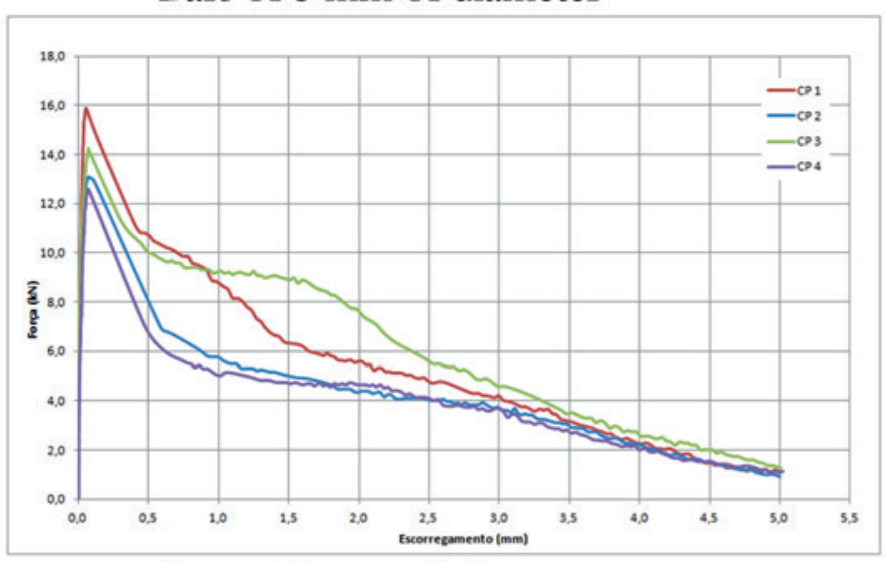

Bars of $8 \mathrm{~mm}$ of diameter

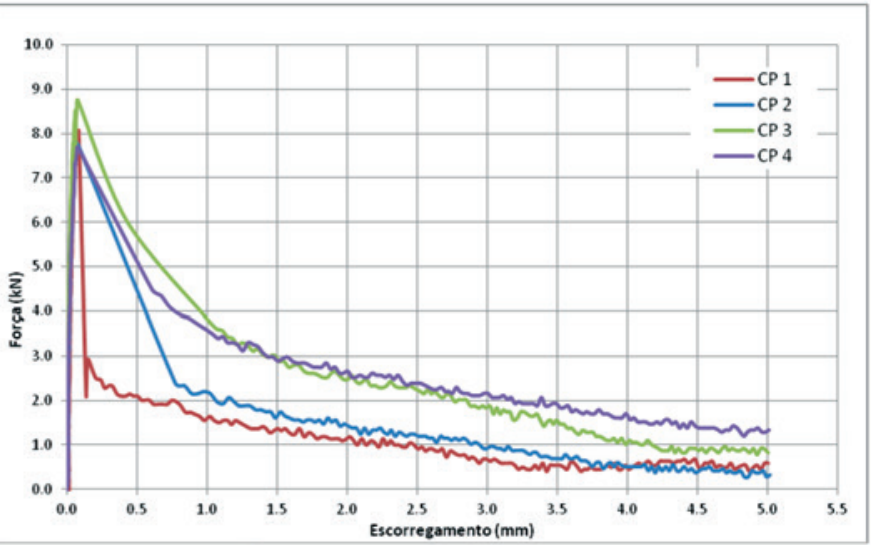

Bars of $6.3 \mathrm{~mm}$ of diameter

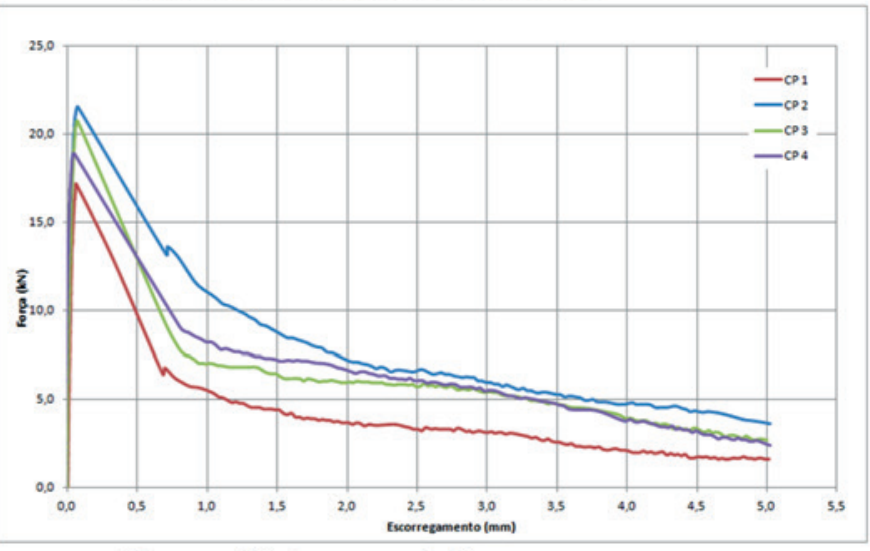

Bars of $10 \mathrm{~mm}$ of diameter

Força means Force, Escorregamento Sliding and CP stands for SP

Figure 14

Curves of force versus sliding of the $3^{\text {rd }}$ batch of SLCEB 
[15] LEONHARDT, F.; MÖNNIG, E. (1977). Construções de Concreto v.1. Rio de Janeiro: Interciência. 305p.

[16] ALMEIDA FILHO, F. M. (2006). Contribuição ao estudo da aderência entre barras de aço e concretos auto-adensáveis. Tese de doutorado. São Carlos, EESC - SET (USP), 2006. 310p.

[17] FUSCO, P. B. (1995) Técnica de armar as estruturas de concreto. São Paulo. PINI. 382p.
[18] ASSOCIAÇÃO BRASILEIRA DE NORMAS TÉCNICAS (2014). NBR 6118: Projeto de estruturas de concreto procedimento. Rio de Janeiro.

[19] CASTRO, C. M. (2012). Concreto de alto desempenho: estudo da aderência com a armadura sob ações repetidas. São Carlos, 2002. 194f. Dissertação (Mestrado em Engenharia de Estruturas) - Escola de Engenharia de São Carlos da Universidade de São Paulo. São Carlos, 2002.

\section{Table 12}

Average values for pull-out tests

\begin{tabular}{|c|c|c|c|c|c|c|}
\hline Batch & $\begin{array}{c}\text { Diameter of the bar } \\
(\mathrm{mm})\end{array}$ & $\begin{array}{c}\tau_{\max } \\
(\mathrm{MPa}) \\
\end{array}$ & $\begin{array}{l}\tau_{0.10 \mathrm{~mm}} \\
(\mathrm{MPa})\end{array}$ & $\begin{array}{c}f_{b d} \\
(\mathrm{MPa})\end{array}$ & Failure mode & $\tau_{0.10 \mathrm{~mm}} / \mathrm{f}_{\mathrm{bd}}$ \\
\hline \multirow{6}{*}{ OC } & 5 & 14.85 & 7.03 & 2.79 & Sliding of the bar & 2.52 \\
\hline & 6.3 & 21.4 & 12.47 & 2.79 & $\begin{array}{l}\text { Yielding and subsequent } \\
\text { sliding of the bar }\end{array}$ & 4.47 \\
\hline & 8 & 13.59 & 7.91 & 2.79 & Sliding of the bar & 2.84 \\
\hline & 10 & 14.85 & 7.52 & 2.79 & $\begin{array}{l}\text { Yielding and subsequent } \\
\text { sliding of the bar }\end{array}$ & 2.70 \\
\hline & 12.5 & 14.78 & 8.12 & 2.79 & $\begin{array}{l}\text { Sliding of the bar with } \\
\text { concrete splitting }\end{array}$ & 2.91 \\
\hline & Average & 15.89 & 8.61 & 2.5 & - & 5.40 \\
\hline \multirow{6}{*}{$\begin{array}{l}\text { SLCEB } \\
1^{\text {st }} \text { Batch }\end{array}$} & 5 & 9.07 & 6.96 & 1.19 & Sliding of the bar & 5.85 \\
\hline & 6.3 & 12.16 & 11.80 & 1.19 & Sliding of the bar & 9.92 \\
\hline & 8 & 11.85 & 11.74 & 1.19 & Sliding of the bar & 9.87 \\
\hline & 10 & 11.95 & 11.63 & 1.19 & Sliding of the bar & 9.77 \\
\hline & 12.5 & 10.02 & 9.45 & 1.19 & $\begin{array}{l}\text { Sliding of the bar with } \\
\text { concrete splitting }\end{array}$ & 7.94 \\
\hline & Average & 11.01 & 10.32 & 2.5 & - & 5.40 \\
\hline \multirow{5}{*}{$\begin{array}{l}\text { SLCEB } \\
3^{\text {rd }} \text { Batch }\end{array}$} & 5 & 14.05 & 13.76 & 1.19 & Sliding of the bar & 11.56 \\
\hline & 6.3 & 12.94 & 12.87 & 1.19 & Sliding of the bar & 10.82 \\
\hline & 8 & 13.88 & 13.86 & 1.19 & Sliding of the bar & 11.50 \\
\hline & 10 & 12.45 & 12.45 & 1.19 & Sliding of the bar & 10.46 \\
\hline & Average & 13.33 & $\begin{array}{c}13.24 \\
(-0.68 \%)^{1} \\
\end{array}$ & 1.01 & - & 11.13 \\
\hline $\begin{array}{l}\text { Preliminary } \\
\text { test }\end{array}$ & 10 & 5.45 & $\begin{array}{c}5.23 \\
(-4.04 \%)^{1}\end{array}$ & 1.01 & $\begin{array}{l}\text { Yielding and subsequent } \\
\text { sliding of the bar }\end{array}$ & 5.18 \\
\hline
\end{tabular}

\section{Table 13}

Comparison of average strength to compression $\left(f_{\mathrm{cm}}\right)$ with the bond stresses

\begin{tabular}{|c|c|c|c|c|c|}
\hline Batch & $\mathbf{f}_{\mathrm{cm}}(\mathbf{M P a})$ & $\tau_{\max }(\mathbf{M P a})$ & $\tau_{0.10 \mathrm{~mm}}(\mathbf{M P a})$ & $\mathbf{f}_{\mathrm{cm}} / \tau_{\max }$ & $\mathbf{f}_{\mathrm{cm}} / \tau_{0.10 \mathrm{~mm}}$ \\
\hline OC & 43.18 & 15.89 & 8.61 & 2.72 & 5.02 \\
\hline SLCEB 1 ${ }^{\text {st }}$ Batch & 10.84 & 11.01 & 10.32 & 0.98 & 1.05 \\
\hline SLCEB 3 3rd Batch $^{\text {S }}$ & 12.27 & 13.33 & 13.24 & 0.92 & 0.93 \\
\hline SLCEB preliminary test & 5.75 & 5.45 & 5.23 & 1.06 & 1.10 \\
\hline
\end{tabular}


[20] RILEM-FIP-CEB. (1973). Bond test for reinforcing steel. 1. Beam test (7-II-28 D). 2. Pull-Out Test (7-II-128). Tentative Recommendations. RILEM Journal Materials and Structures, v.6, n.32, p.96-105. Mar./Apr. 1973. 